\title{
Motile Cilia and Airway Disease
}

Marie Legendre ${ }^{a *}$, Laure-Emmanuelle Zaragosi ${ }^{b *}$, Hannah M. Mitchison ${ }^{c, d}$

a Sorbonne Université, Institut National de la Santé et de la Recherche Médicale, Childhood Genetic Disorders, Département de Génétique Médicale, Hôpital Armand-Trousseau, Assistance Publique-Hôpitaux de Paris, Paris 75012, France.

b Université Côte d'Azur, CNRS, IPMC, Sophia-Antipolis, 06560, France.

' Genetics and Genomic Medicine, University College London, UCL Great Ormond Street Institute of Child Health, London WC1N 1EH, UK.

d NIHR Biomedical Research Centre at Great Ormond Street Hospital, London, UK.

* Equal contribution.

\section{Correspondence:}

Professor Hannah Mitchison

Cilia Disorders Section

Genetics and Genomic Medicine Research \& Teaching Department

UCL Great Ormond Street Institute of Child Health

London WC1N 1EH, UK.

Email.h.mitchison@ucl.ac.uk. 


\begin{abstract}
A finely regulated system of airway epithelial development governs the differentiation of motile ciliated cells of the human respiratory tract, conferring the body's mucociliary clearance defence system. Human cilia dysfunction can arise through genetic mutations and this is a cause of debilitating disease morbidities that confer a greatly reduced quality of life. The inherited human motile ciliopathy disorder, primary ciliary dyskinesia (PCD), can arise from mutations in genes affecting various aspects of motile cilia structure and function through deficient production, transport and assembly of cilia motility components or through defective multiciliogenesis. Our understanding about the development of the respiratory epithelium, motile cilia biology and the implications for human pathology has expanded greatly over the past 20 years since isolation of the first PCD gene, rising to now nearly 50 genes. Systems level insights about cilia motility in health and disease have been made possible through intensive molecular and omics (genomics, transcriptomics, proteomics) research, applied in ciliate organisms and in animal and human disease modelling. Here, we review ciliated airway development and the genetic stratification that underlies PCD, for which the underlying genotype can increasingly be connected to biological mechanism and disease prognostics. Progress in this field can facilitate clinical translation of research advances, with potential for great medical impact, e.g. through improvements in ciliopathy disease diagnosis, management and family counselling as well as enhancing the potential for future genetically tailored approaches to disease therapeutics.
\end{abstract}

\title{
Key words:
}

Cilia, airway, respiratory, disease, primary ciliary dyskinesia, reduced generation of motile cilia 


\section{The multiciliated human airways and their cellular composition}

The human respiratory tract is lined by a mucociliary epithelium that covers the airway surfaces from the nose to the most distal segment of the conducting airways (the terminal bronchioles). Within the airway epithelium, mucus-producing cells and ciliated cells bearing multiple motile cilia together provide a vital airway defence system of mucociliary clearance, by the constant trapping and upward motility of inhaled particles and pathogens, with secretions finally expelled at the nose and mouth or removed at the nasopharynx by swallowing. The airway epithelium is composed of five main cell types: basal, suprabasal, club, goblet and multiciliated cells (Figure 1). The cellular heterogeneity across the upper and lower airways in the healthy airways has been explored through global transcriptomics, as well as the characterisation of some lung disease states e.g. asthma, pulmonary fibrosis. Reference airway cell atlases now reveal an unprecedented molecular detail and almost complete cellular definition, with the exception of some very rare unidentified cell types [1-4] (Figure 1). Rare cell types include ionocytes, neuroendocrine as well as tuft cells [3]. Better understanding of the formation and composition of the airway epithelium has been an intensive area of biological and translational research over recent years. Genetic lineage labelling has established a comprehensive profiling of airway epithelial cell lineage in mice. Recently, the advent of single-cell transcriptomic analysis (RNA sequencing), coupled to lineage inference algorithms has suggested lineage relationships in humans [5]. In both organisms, the main developmental model implies that basal cells first differentiate into club cells, by going through a suprabasal cell intermediate. Club cells in turn mature into goblet cells or differentiate into multiciliated cells. Some authors have proposed that goblet cells could also differentiate into multiciliated cells, as goblet cells are found on the multiciliated cell branch in airway lineage inference studies, and furthermore because of the identification of hybrid mucous multiciliating cells $[2,3,6,7]$.

We now know that basal cells, identified by the expression of KRT5 and TP63, populate the epithelium all along the airway tree in humans, although their abundance decreases in smaller airways [8]. Basal cells are the progenitors of all other cell types of the epithelium [9] and they generate a strong cohesion of the epithelium through their attachment to the basal lamina [1012]. Suprabasal cells share many similarities with basal cells, including the expression of KRT5, but they have lost TP63 expression, are not adjacent to the basal lamina and display features of early committed progenitors such as Notch pathway activation [7, 13].

Club cells are luminal cells that secrete anti-inflammatory and immune-modulating compounds such as secretoglobin 1A1 (SCGB1A1) [14-16] and participate in xenobiotic detoxification [17]. During epithelial regeneration, whether upon injury or at homeostasis, club cells differentiate from suprabasal cells. Despite their differentiated phenotype and specialized function, they can, in turn, differentiate into multiciliated cells. This differentiation pathway has been termed physiological "transdifferentiation" [18].

Goblet cells are also luminal secretory cells, identified by their property of mucin secretion. Secreted respiratory mucins are the main contributors to the formation of the airway mucus "gel", predominantly MUC5AC produced by goblet cells of the surface epithelium and MUC5B produced by the goblet cells of the submucosal glands [19, 20]. Trapping of airborne particles occurs within the surface liquid lining the airways, which forms an approximately $5 \mu \mathrm{m}$-thick continuous layer [21]. This surface liquid can be divided into two distinct phases or layers: a gel phase corresponding to the mucus layer, which is the outermost layer, and a periciliary fluid which includes motile cilia. Mucus is gradually drained out of the airways with the coordinated beating of cilia of the respiratory epithelial multiciliated cells.

Multiciliated cells are $20 \mu \mathrm{m}$-high (basal to apical surface) cylindrical or pyramidal cells that carry about 200 to 300 motile cilia on their apical surface, which is about $6 \mu \mathrm{m}$ across [22]. Cilia are hair-like structures with a highly organised internal microtubule-based structure 
(axoneme), that protrude out from the apical surface into the extracellular space, to a height of about $7 \mu \mathrm{m}$, diameter $0.3 \mu \mathrm{m}$. The motile cilia beat at a frequency between 10 and $20 \mathrm{~Hz}$, resulting in a mucus displacement of about $5 \mathrm{~mm} / \mathrm{min}[20,23,24]$. Cilia beating movement is characterized by an effector phase, during which the cilium is perpendicular to the plane of the epithelium and the ciliary end is anchored to the mucus layer. The cilium moves in a single plane and in the direction of mucus evacuation, which is followed by a recovery phase, during which the cilium curves to return to the initial position [25]. Although cilia beating is usually referred to as synchronous, it is rather slightly shifted in time, causing a wave on the surface of the epithelium. Between the cilia there are intercalated microvilli, that reach to about half the height of cilia on the apical surface [26, 27].

\section{Regulation of airway multiciliogenesis}

The multiciliogenesis pathway is a highly conserved process of cellular development and differentiation that has proved amenable to molecular investigations through human genetic and animal model studies, as shown in Figure 2.

One of the major steps of multiciliogenesis is centriole amplification, which takes place in an intermediate cell state between club and mature multiciliated cells. It is generally considered that $10 \%$ of newly-formed centrioles emerge from parental centrioles, and $90 \%$ emerge from deuterosomes, which are membrane-less protein organelles, rich in DEUP1 protein [28-32]. Although deuterosomes have been proposed to be nucleated from the younger parent centriole [32] and may have evolved to relieve, rather than supplement centriole amplification from the parental centrioles, recent studies have shown that the $\sim 300$ neosynthesized centrioles can emerge spontaneously in a cloud of pericentriolar material when both parental centrioles and deuterosomes are depleted [33, 34]. Each centriole then matures into a basal body which, after anchoring at the basal membrane, serves as the nucleation site for outgrowth of microtubules that form the axoneme scaffold for generation of one of the multicilia.

Among multiciliogenesis regulatory pathways, Notch signalling plays a central role during airway development and regeneration, since the activation of Notch pathways leads to the differentiation of basal cells into secretory cells types, while its inhibition is required for differentiation of multiciliated cells [35-38]. Notch inhibition leads to the transcriptional induction of two major transcriptional regulators: Multicilin (MCIDAS) and GMNC. GMNC, which is also inhibited by Geminin (GMNN), stimulates MCIDAS expression and interacts with both E2F4/5-TFDP1 and MCIDAS to form a quaternary complex [39-42]. MCIDAS is identified as a transcriptional regulator of multiciliogenesis, acting at an early stage. By using a tracer SASS6 Xenopus fusion protein, Stubbs et al. have highlighted the role of MCIDAS in centriole assembly, which is a prerequisite for the formation of multiple motile cilia [43]. In addition, they showed that MCIDAS induces the expression of genes involved in multiciliogenesis, such as FOXJ1. Like GMNC, MCIDAS forms a ternary complex with E2F4 (or E2F5) and TFDP1 to activate cilia-related gene expression [44]. E2F4 or E2F5 deficiency alone also blocks multiciliogenesis [45, 46]. Furthermore, ChIP-seq experiments (chromatin immunoprecipitation with massively parallel DNA sequencing to identify the binding sites of DNA-associated proteins), to analyse the DNA-binding of E2F4 alone or in combination with MCIDAS, showed a clear enrichment of E2F4 binding to genomic regions corresponding to centriole biogenesis genes for their regulation [44]. The proposed model is that GMNC first forms a complex with E2F4/5-TFDP1 to induce differentiation genes, in particular MCIDAS, which associates with the complex and reinforces the induction of key factors for the biogenesis of motile cilia such as MYB, FOXJ1, FOXN4 or RFX3. An additional regulator of multiciliogenesis is TP73, which is expressed in a fraction of basal cells, but predominantly in multiciliated cells. Tp73-deficient mice remain capable of amplifying centrioles, but the centrioles are not able to anchor at the apical membrane, are not polarized and do not grow 
axonemes. TP73 expression is induced by MCIDAS and it is found to regulate RFX2, RFX3 and FOXJ1 [47, 48].

FOXJ1 is a transcription factor expressed in all tissues carrying motile cilia: brain ventricles, fallopian tubes, testes, and the embryonic node [49-51]. Foxj1-deficiency in mouse results in complete absence of motile cilia [52]. FOXJ1 is required for maturation, migration and/or apical anchoring of the centrioles, and for axoneme elongation and mobility [49, 53-55]. FOXN4 has been described as a co-activator of FOXJ1 targets in Xenopus [56, 57]. The RFX (Regulatory Factor binding to the $X$ box) transcription factors form a family of nine members, but only 3 of them (RFX2, RFX3 and RFX4) have a functional link with motile cilia [58]. RFX3 regulates cilia length and mobility, in particular through binding to the dynein promoters and activation of their expression [59]. RFX factors induce the expression of a large number of proteins participating in the structure of the cilia (e.g. dyneins) and in particular proteins involved in intraflagellar transport of ciliary cargos $[54,60]$. In a co-regulatory mechanism possibly through formation of a transcriptional complex, FOXJ1 can induce the expression of RFX2 and RFX3 [61] and conversely, RFX3 may bind to the FOXJ1 promoter and induce its expression [59].

Amongst multiciliogenesis regulators are found microRNAs (miRNAs), short endogenous noncoding RNAs that can bind to the 3 '-untranslated regions of target genes to inhibit their expression. $m i R-449$ and $m i R-34 b / c$ are specifically expressed during centriole amplification and ablation of miR-34/449 in vitro in human airway epithelial cells, or in vivo in knock-out mice, results in impaired centriole amplification and blocked multiciliogenesis [62, 63]. $C D C 20 B$, the host gene which harbours the entire miR-449 family, is itself involved in centriole amplification. CDC20B protein is found at the deuterosomes, required at the centriole disengagement step that is necessary for centriole duplication [28]. Intriguingly, human MCIDAS and CDC20B/miR-449 are located together at the same genomic locus on chromosome $5 \mathrm{q} 11.2$ and furthermore, $C D C 20 \mathrm{~B} / \mathrm{miR}-449$ expression is controlled by MCIDAS $[28,54]$. A third regulator of multiciliogenesis, CCNO (cyclin-O) is located in close vicinity to MCIDAS and CDC20B/miR-449. One of the cyclin protein family required for cells to progress through the cell cycle, CCNO expression is also controlled by MCIDAS [44] and it is involved in the early steps of deuterosome-mediated centriole amplification [64]. There are reduced deuterosome numbers in airway multiciliated precursor cells of Ccno mutant mice, leading to reduced numbers of centrioles and sparse numbers of motile cilia such that the mice display a typical motile cilia-related disorder, with impaired mucociliary clearance [65]. The chr 5q11 region is therefore a key locus for regulation of multiciliated cell differentiation.

The up-regulation of structure and motility components at the later stage of multiciliogenesis is accompanied by other essential multiciliogenesis controls. These include different cell polarity factors and hydrodynamic forces involved in cilia orientation and coordinated beating, as has been reviewed elsewhere [66].

\section{Airway epithelium modification in disease}

There is significant potential for damage to the delicate airway epithelial defence system of mucus clearance through its daily exposure, via respiration, to inhaled pathogens, toxins and immunological challenges. In addition, genetic factors and pathogenic gene mutations contribute to a spectrum of 'muco-obstructive' airway diseases, which includes a range of complex conditions, such as chronic obstructive pulmonary disease (COPD), non-cystic fibrosis bronchiectasis, asthma, chronic bronchitis.

The spectrum also includes inherited single gene disorders causing monogenetic disease [67], such as the rare genetic diseases primary ciliary dyskinesia (PCD) and cystic fibrosis (CF). PCD and CF have an overlapping spectrum of repeated infections and bronchiectasis implicating cilia dysfunction. However, their disease aetiology is completely distinct: PCD is 
the major inborn disease known to be directly caused by airway cilia structure/function mutations i.e. mutations that affect the motile cilium's axoneme generation or its structural organisation. In CF, cilia dysplasia and axonemal structural abnormalities of motile cilia may be seen in affected patient's airways [68,69], but this is for different reasons that relate to a physical interference with normal mucociliary clearance/movement of cilia. CF is caused by mutations in the cystic fibrosis transmembrane conductance regulator (CFTR), which is expressed in the multiciliated cells, but at low levels, with much higher expression in ionocytes $[5,70]$. CFTR mutations dysregulate airway epithelial ion transport, resulting in increased epithelial fluid absorption and decreased water content, altering mucus properties and mucociliary interactions.

Several of the multiciliogenesis regulatory genes are now recognised to be associated with disease arising from cilia dysmotility (PCD), as shown in red in Figure 2. In addition, a team recently found that IL-13, induced in chronic conditions such as asthma, inhibits MCIDAS independently of the Notch pathway [71]. In terms of ciliopathy, much about the underlying biological mechanisms has been revealed through human genetics. A mutation of multicilin (MCIDAS) was found in PCD patients with a subtype termed "Reduced Generation of Multiple Cilia" (RGMC). Their ciliated airway cells lacked multiple basal bodies and displayed drastically reduced numbers of cilia that were furthermore static, also having ultrastructural defects demonstrating a lack of the motility protein apparatus in the remnant cilia [72]. CCNO mutations were also detected in PCD patients with similar RGMC lack of mutlicilia, but in this case the defect lay in the basal body biogenesis program, downstream of the MCIDAS master regulation of multiciliated cell differentiation. CCNO deficiency affects the amplification and anchoring of centrioles, resulting in cilia of reduced number but retaining normal cilia ultrastructure and motility (i.e. not lacking the motility proteins) [73]. FOXJ1 mutations were also identified to cause RGMC, with a reduced number of cilia that interestingly had a mixture of dysmotility, with both normal and structurally disorganised airway cilia. FOXJ1 mutations are distinguished by causing the only dominant form of PCD, through haploinsufficiency in carriers of a single FOXJ1 mutation [74]. GMNC is, like MCIDAS, a critical master regulator of multiciliated cells differentiation and a candidate gene for human RGMC. Consistent with this, Gmnc-deficient mice lack airway multiciliated cells, but no human patient mutations have yet been reported [42].

Many genes are known to regulate cilia length, but recent human mutational studies identified an interesting additional regulator of multiciliogenesis, NEK10, that is worth highlighting in the context of PCD. Mutations in NEK10, a ciliated cell-specific serine-threonine kinase from the NIMA (never in mitosis gene a)- related kinase (NEK) cell cycle protein family, give rise to muco-obstructive airway disease akin to PCD with bronchiectasis. However, uniquely within this disease spectrum, NEK10 mutation is associated with shortened motile cilia (of normal structure and motility), accompanied by reduced motile cilia protein expression but also widespread ciliary proteome depletion. NEK10 mutations also do not confer the defect of undocked centriole/basal bodies seen in cilia aplasia syndromes arising from MCIDAS, CCNO and FOXJ1 mutations [75].

\section{Clinical features of motile ciliopathies with airway disease (PCD)}

The clinical course of airway disease in PCD motile ciliopathies is shown in Figure 3. This usually includes an early onset, manifesting as neonatal respiratory distress syndrome. Affected individuals have chronic upper and lower airway symptoms, which features recurrent sinusitis, rhinitis, congestion and nasal polyps, daily productive cough, continual respiratory infections, recurrent pneumonia. The ear canal is affected with chronic infections, otitis media and often conductive hearing loss. There is a progressive loss of lung function through the effects of bronchiectasis, whereby the airways become inflamed, scarred and enlarged with excessive mucus creating susceptibility to infections. 
A wider spectrum of clinical symptoms characterises the PCD-RGMC motile ciliopathies, as dysfunction of motile cilia affects not only the respiratory tract but also several other specialised regions of the body involved in fluid flow across epithelia and transport of cells through fluid. This can result in left-right axis organ displacements and subfertility; hydrocephalus may (sporadically) also occur, notably more frequently in RGMC (Figure 3). These non-airway features arise from dysmotile cilia on the epithelial surfaces of, respectively, the embryonic left-right (L-R) organiser (monocilia), the oviduct and the brain ventricles (multicilia). Additionally, structurally related axonemal dysmotility of the sperm flagella causes frequent male infertility [76]. Ependymal cilia of the ventricles influence the movement and likely also composition of the cerebrospinal fluid, whilst nodal monocilia within the L-R organiser determine organ laterality early during development $[77,78]$. In PCD, laterality determination is randomised, with only about half patients having normal arrangement of the internal organs (situs solitus, SS). The other half have situs inversus and heterotaxy, most often manifesting as situs inversus totalis (SIT) involving medically harmless mirror-image organ displacement e.g. dextrocardia. However in $6-9 \%$ there is more complex situs ambiguous (SA) associated with cardiac defects like isomerisms, that may require surgical intervention. Congenital heart disease has been found in 6-17\% of PCD patients, occurring in fact across all of SS/SIT/SA, but much more frequently in SA cases [79-81]. PCD patients with heart defects and heterotaxy are also at higher risk of more severe respiratory complications [82].

\section{Genetics of PCD and molecular diagnostics}

A timeline of events in PCD research and gene discovery is shown in Figure 4. Since 1999 and the isolation of DNAl1, the first PCD gene (Pennarun et al.), almost 50 genes have been found to be mutated in this condition (Figure 5). Internally, the motility of cilia is supported by their anciently conserved microtubular axoneme core scaffold, arranged in a classical $(9+2)$ structure of a central microtubular pair surrounded by nine peripheral microtubules (Figure 5). Gene mutation-related disturbance of the 9+2 axoneme is associated with a spectrum of motile ciliopathy disease within the PCD category. The inheritance mode is mostly recessive as only three genes are associated with a recessive X-linked transmission (RPGR, PIH1D3, and OFD1) and one with dominant inheritance (FOXJ1). As for all recessive disorders, the incidence of PCD is higher in populations where endogamy is frequent and a number of founder effect mutations have arisen through genetic isolation.

PCD diagnosis is complicated by disease variability and the need for expert verification of cilia dysfunction. Diagnostic screening is specialised and multifaceted, best performed at a specialist centre and employing a number of measures of ciliary motility (low nasal nitric oxide, tests of cilia structure, function, dyskinesia index), which have established clinical guidelines for their relative specificity and sensitivity $[83,84]$. The main differential diagnoses are cystic fibrosis and immunodeficiencies. Given the genetic heterogeneity of PCD and the large size of most of the causative genes, such as the dynein heavy chains and HYDIN, gene-based molecular diagnosis now relies on massive parallel high throughput sequencing by targeted panel, whole exome or whole genome sequencing approaches. Acknowledged challenges in PCD patient gene sequence interpretation also include multiple disease alleles, often found in just one or two families, including 'hidden' splicing defects or single amino acid substitutions $[85,86]$. Mutation nomenclature and the classification of DNA variants as causal-pathogenic requires a rigorous approach, employing the consensus guidelines of the Human Genome Variation Society and the American College of Medical Genetics [87, 88]. Within these rules, the diagnostic rate for PCD is high, reaching $70-75 \%$, in patients with a highly probable PCD phenotype that is based on indicative clinical signs such as low nasal nitric oxide; and suggestive ciliary investigations such as defects being found using ciliary beat analysis by high-speed video microscopy, axonemal structure analysis by transmission electron microscopy or ciliary protein expression by immunofluorescence [85, 89-91]. Since the causal additional PCD genes and variants remain to be identified in $\sim 25 \%$ of PCD cases, genetics is 
not yet a stand-alone gold standard test, however the contribution of genetics is indisputable and increasingly implemented within clinical diagnostic settings [84]. Genetic screens have proven able to diagnose patients lacking detailed cilia functional analysis, so a gene panel- or exome-first approach has been advocated especially for less well-resourced clinical centres $[85,90]$.

The genetic spectrum varies between geographic areas. In patients with European ancestry, the major causes are mutations in the DNAH5 and DNAH11 dynein heavy chains of the outer dynein arms of airway cilia and a European CCDC40 mutation accounts for many cases. In some other populations, recurrent ancestral mutations are frequently found in patients, such as the CCDC103 p.(His154Pro) missense mutation carried (20\% are homozygous) by South Asian ancestry PCD patients [92], a recurrent Arabic RSPH9 p.(Lys268del) mutation [85], or a CCDC39 c.2190del mutation in North African patients (24\% homozygotes in Tunisian patients [93]). This type of recurrent specific mutation can be targeted for screening first, especially if high-throughput techniques are not readily available.

\section{Mutations in PCD genes impair the structure and/or the function of the axoneme}

A tight correlation exists between the implicated gene in PCD patients and the axonemal ultrastructural phenotype of their respiratory cilia (Table 1) and/or their sperm flagella. Apart from RPGR and OFD1 associated to a more syndromic phenotype, PCD genes can be divided into three main groups of proteins, in which mutations confer ciliary defects consistent with their known biological functions (Figure 6 and see Table $\mathbf{1}$ for references). The first is the previously mentioned group of transcription factors and transcriptional regulators involved in multiciliogenesis (CCNO, FOXJ1, MCIDAS) in addition to the new player NEK10 involved in control of cilia length (Figure 2). The second encompasses components of axonemal structure, e.g. DNAH5 and DNAH11 dynein heavy chains of the outer dynein arms, HYDIN the C2b projection of the central pair complex, CCDC39 and CCDC40 the molecular ruler proteins and RSPH1, 3, 4A, 9 radial spoke head proteins. Amongst the gene group linked to structural defects, the localisation and roles of NME5 and STK36 remain less clear [94, 95].

The third is a collection of now at least 15 proteins participating within large complexes to drive the folding, stabilization and assembly and/or transport of axonemal outer and inner dynein arm motors, first recognised with isolation of the PCD gene DNAAF2 in 2008 [96]. Research in Chlamydomonas, mouse, Xenopus, fly and humans shows a complex program of dynein pre-assembly in the cytoplasm mediated by client/chaperone functions of DNAAFs (dynein axonemal assembly factors). Dynein arm 'clients' are stabilised and assembled by DNAAFs that participate as co-chaperones to recruit HSP90 chaperone protein(s), to assist the dyneins to fold and stabilise. These assembly complexes, by homology and binding screens, appear analogous in function to the R2TP complex. R2TP, composed of two DNA helicases, RUVBL1 and RUVBL2, PIH1D1 and RPAP3, recruits HSP90, allowing it to stabilise, fold and help assemble non-ciliary protein clients [97]. Of the PCD-implicated assembly factors, DNAAF4, SPAG1 and CCDC103 have RPAP3 homology, while DNAAF2 and DNAAF6 have PIH1D1 homology [86, 98]. Human RUVBL2 interacts with LRRC6, which interacts with ZMYND10, implicating both these PCD proteins as partners in R2TP type assembly complexes [99, 100].

Other interactions amongst the PCD dynein assembly factors have been identified and multiple DNAAFs appear to concentrate together with axonemal dyneins and chaperones into cytoplasmic assembly organelles ("DynAPs") specific to multiciliated cells, which have liquidlike behaviours [101]. Much remains to be defined in this pathway, e.g. CFAP298 has unknown function [102], DNAAF5 and DNAAF6 are thought to act at an initial step of dynein arm assembly involving ODA intermediate chains [103], while DNAAF1, DNAAF2 and DNAAF3 work together to assemble the ODA heavy chains [104]. Rather than pre-assembly of entire dynein motors in the cytoplasm, a more sequential assembly into the axonemes during ciliogenesis has been proposed, as well as potential for early and late assembly complexes 
$[105,106]$. Different DNAAFs appear responsible for assembly of distinct dynein arm subunits, for example two cytoplasmic PCD proteins, DNAAF6 and TTC12, govern assembly of selected inner dynein arm components as well as aspects of ODA assembly [86, 107].

Once assembled, or sequentially assembled, the dynein motors are imported from the cytoplasm into cilia which requires intraflagellar transport (IFT), mediated by the transport adaptor DAW1 (ODA16) interacting with the IFT complex-B protein IFT46 to facilitate their transport from the cilia base to tip [108]. PCD-causing mutations have not been reported in either DAW1 or IFT46, but other later acting PCD associated partners in this process are CFAP300 which localises in the cytoplasm but also interacts with axonemal IFT [109]. Intriguingly, DNAAF1 is reported to interact with IFT88, a partner of IFT46 within IFT complex$B$ [110]. There are also partners in dynein arm assembly reported to localise solely to the axoneme: LRRC56, participating in ODA assembly at the distal cilium [111] and CFAP57, participating in assembly of inner dynein arm components [112].

Finally, outside the axoneme itself, PCD-causing mutations have also been reported in GAS2L2, a ciliated cell-specific protein localised to basal bodies, basal feet, rootlets, and actin filaments. Patients with GAS2L2 mutations have a normal ciliary axoneme structure but an asynchronous ciliary beat, linked to defects in ciliary orientation [113].

\section{Genotype-phenotype correlations and ciliary investigations}

Axoneme structure defects and abnormal cilia beat patterns characterized in PCD patients correlate highly with the implicated gene [114-116]. This finding is used in disease diagnosis, as PCD diagnosis requires a confirmation of consistency between ciliary and genetic investigations, especially if at least one of the alleles carries a variant of uncertain pathogenic significance [83]. Mutations in multiciliogenesis causing RGMC-type PCD are structurally unique, with greatly reduced respiratory cilia numbers. Mutations in genes encoding ODA and ODA docking components (e.g. DNAH5, CCDC151) lead to absent and/or shorter dynein arms in respiratory cilia that are also mostly immotile or show a low beat frequency. One exception is DNAH11 where, due to a masked ODA localisation and its proximal localization in the axoneme (Figure 6), its absence is missed by routine TEM as the axoneme structure appears normal [117]. DNAH11 mutations also cause a specific pattern of low-amplitude hyperkinetic ciliary beat with vibrating cilia, connected to a motility defect limited to the proximal cilia portion where that protein is located [117] (Figure 6). Dynein assembly protein mutations cause a lack of dynein arms in TEM, with practically immotile cilia. One exception is the p.(His154Pro) CCDC103 mutation, associated with only moderate structural and beat impairment [92]. Mutations in CCDC39 or CCDC40, the $96 \mathrm{~nm}$ axonemal rulers, cause a specific disorganization of absent inner dynein arm, central apparatus defects, and microtubular disorganization, conferring a low percentage of beating cilia (stiff cilia with reduced beat amplitude) [118-120]. Central microtubule complex defects arising from mutations in components of the complex itself or the radial spokes underlie subtle anomalies that can be missed by TEM and/or high-speed video microscopy and cilia beat impairment can also be moderate. Mutations in the nexin-dynein regulatory complex (N-DRC) also lead to inconstant and mild axonemal disorganization and moderate beating alteration. Other specific TEM disturbances for the known PCD genes are detailed in Table 1.

\section{Genotype-phenotype correlations in clinical expression}

$C C D C 39$ and $C C D C 40$ mutation patients presenting with this major axonemal disruption also tend to have worse lung function than patients with isolated outer dynein arm defects [121]. CCDC39/40 patients tend to have significantly lower percent predicted FEV1 and weight and height z-scores, accompanied by significant lung function decline over time, which is not found in patients with other ultrastructural defects. Landmark Chlamydomonas single-particle cryoelectron microscopy imaging contrasts the effects of mutations in proteins attached to the 
outside versus the inside of the peripheral microtubule doublets. Outer proteins CCDC39, CCDC40, CCDC114 and CCDC151 are linked to PCD, the CCDC39/40 complex serving a critical role stretching along the entire axoneme to space axonemal complexes out with a 96$\mathrm{nm}$ repeat, which may explain the disease severity. In contrast, mutations of microtubule inner proteins (MIPs) appear to affect nodal more than than respiratory cilia (possibly due to a greater nodal cilia mechanical stress). Hence, where respiratory cilia have been examined (for MNS1 and NME7 mutations and reviewed in [122]), there is little to no disturbance [123-125], with expression in affected individuals of laterality and sperm defects but not PCD.

'Milder' PCD disease may also occur in patients with GAS2L2 and LRRC56 mutations that are found in patients with an apparently undisturbed cilia ultrastructure in TEM investigations [111, 113]. Individuals with RSPH1 mutations, who have central complex defects, but a high proportion of normal TEM cilia (reportedly overlapping with the range in healthy controls), also show a better lung function (significantly higher FEV1) and low neonatal respiratory distress with daily wet cough occurring later in life than for typical PCD [126]. DNAH9 is also linked to a mild respiratory phenotype and subtle ciliary alterations, with disease restricted to recurrent airway infections [127] or to upper airways [128]. There is a slight motility defect of the distal cilia portion, in keeping with the regional, distal localization of this $y$ ODA dynein heavy chain in airway cilia (Figure 6).

Whilst laterality defects affect about half of patients, there are several PCD genes in which mutations do not cause left/right patterning defects. These include N-DRC mutations as the nodal cilia are not disturbed [102, 129-131] and as nodal cilia lack a central complex there are also no laterality problems in patients with central complex or radial spoke mutations [79]. Although mutations in the multiciliogenesis genes (CCNO, MCIDAS) also do not cause laterality defects as described above, because nodal cilia are monomotile, they do manifest with a comparatively severe mucociliary clearance disorder and have higher instances of hydrocephalus, suggesting a lack of cilia affects fluid flow in the airways and brain more greatly than cilia being present but dysmotile. Hydrocephalus, linked to impaired motility of ependymal cilia, is a key phenotypic feature in PCD mouse mutants, but is rarely found in PCD patients except for RGMC patients. The exception in RGMC is FOXJ1 mutation patients who do get laterality defects, since the motile nodal cilia are generated through a distinct ciliogenesis program controlled by the NOTO transcription factor which requires FOXJ1 [74].

As some male and female PCD patients are fertile, it has been suspected that different axonemal protein composition in airway cilia and Fallopian tubes and sperm cells could explain a preserved fertility in some cases. Interestingly, a majority of male and female patients with DNAH5 and DNAH11 mutations - major outer dynein arm motor genes - and for whom fertility data were available, conceived spontaneously [132], when it was also shown that ODAs were present in spermatozoa axonemes in DNAH5 patients [133]. Recent data confirmed that human airway multiciliated cells and sperm cells harbour distinct compositions in outer arm dynein heavy chains (Figure 6). In airway cilia, DNAH5 is the ODA y heavy chain and DNAH9 and DNAH11 the $\beta$ heavy chain (in distal versus proximal axonemal portion). In sperm cells ODA, DNAH8 is the $y$ heavy chain and DNAH17 the $\beta$ heavy chain. There is a preserved or moderately impaired fertility of male patients with DNAH5 or DNAH11 mutations, whilst $D N A H 8$ and DNAH17 mutations cause isolated male infertility without any respiratory symptoms [134, 135]. In affected PCD males carrying CCDC114 mutations, their lack of infertility has also been suggested to arise from genetic redundancy, as CCDC63 could replace CCDC114 function in sperm [136]. Conversely, there is potential for many cases of MMAF (multiple morphological abnormalities of the sperm flagella) to have previously unrecognised or milder respiratory symptoms, for example when SPEF2 is involved $[137,138]$. The fertility of male patients with DNAH5 mutations is still lower than the average, possibly because multiciliated cells specific to the male reproductive tract could also play a role as an additional/alternative contributor to male infertility in PCD patients, as recently suggested from studies in mice lacking multiciliated cells in the efferent ducts (Terre et al., Development, 
2019). The composition of the axoneme of multiciliated cells of the female reproductive tract is still poorly characterised [139].

\section{Overlap between primary cilia and motile cilia defects}

Motile cilia and primary cilia share mechanisms in their assembly, structure and function and several ciliopathies due to primary cilia defects have emerged to be associated with motile cilia anomalies of the respiratory epithelia and PCD symptoms. In males, RPGR mutations are responsible for isolated retinitis pigmentosa or for an inborn PCD phenotype combined with retinitis pigmentosa occurring later in life [140]. In these patients, the airway cilia axonemes show various structural defects inked to respiratory disease. The CEP290 gene, mutations in which cause Leber congenital amaurosis, is highly expressed in the retina and nasal epithelial cells, but respiratory cilia analysis also reveals a variable proportion of short cilia together with polymorphic structural anomalies accompanied by recurrent moderate upper and lower airway inflammatory disease. [141]. INVS mutations, classically associated with nephronophthisis, have been found to drive situs inversus and recurrent bronchitis, with central complex defects characterized in tracheal cells of one foetus [142]. OFD1 mutations cause the oral-facial-digital type 1 syndrome with an X-linked dominant inheritance and lethality in males, however in 2006 OFD1 mutations were found in males with severe mental retardation, macrocephaly, and recurrent respiratory tract infections linked to impaired ciliary motility; female carriers appear asymptomatic [143]. More recently, hemizygous OFD1 frameshift mutations located in exons 20 and 21 have been characterized in several males with X-linked recessive non-syndromic PCD [144, 145]. In patients with Bardet-Biedl syndrome, assessment of respiratory epithelial cells showed significant ciliary depletion and goblet cell hyperplasia, in keeping with an increased prevalence of neonatal respiratory distress at birth, asthma, otitis media, and rhinitis found in BBS patients [146].

\section{Discussion and future developments}

Recent years have seen unprecedented progress in defining the molecular, cellular and developmental nature of the human ciliated airway in health and disease [147-149]. Alongside this progress, Bjorn Afzelius's statement 40 years ago that "the symptoms of Kartagener syndrome [PCD today] are all directly or indirectly a consequence of the inborn inability of the cilia to move or to perform normal and coordinate movements", still holds true [150].

It took a further 18 years to determine the first inherited cause of PCD/Kartagener syndrome [151], followed by revelation of the extensive genetic heterogeneity we now know to underlie motile ciliopathy. The subsequent progress in new and translational biology arising from PCD human genetics research, has often been underpinned by molecular work in ciliate organisms $[104,111,112,122,152]$. Initially, the discovery of new causes for PCD relied on the screening of candidate genes characterized in algal or animal ciliated/flagellated models such as Chlamydomonas, Tetrahymena, Xenopus, sea urchin, zebrafish and mouse. Since the 2010s, with development of high throughput sequencing techniques, the pace of discovery of new aetiologies has increased, however validation of new PCD causes and the understanding of the pathways and mechanisms governing motile cilia assembly and function still significantly relies on ciliate model organisms [107, 109, 153]. In parallel, cellular models arise, such as the targeted gene ablation possible by CRISPR-Cas9 in human epithelial nasal cells cultured and differentiated in vitro $[75,107]$. The genes implicated in recent years still do not explain all cases, with genetic cause unknown in about $25 \%$ of the patients. The underlying causes may involve new genes or more comprehensive screening of known genes (e.g. their noncoding regions), which should in future be revealed by wider implementation of genetic screening and new developments such as whole genome sequencing.

We have gathered a better nuanced knowledge of motile ciliopathy disease stratification, according to genotype and ethnicity. The future power of translational human genetics lies in 
collaborative research, larger clinical consortia and more unified research networks for recruitment and characterisation of larger PCD patient cohorts. Initiatives such as BEAT-PCD, ERN-LUNG and the Genetic Disorders of Mucociliary Clearance Consortium (GDMCC) help to increase patient numbers and statistical significance, facilitating better understanding of genotype phenotype correlations of clinical importance and of PCD disease modifiers. This in turn can help to promote more accurate and genetically targeted approaches for family counselling, genetic therapies and development of disease-modulating drugs. 


\section{Acknowledgements}

With thanks to the PCD Family Support Group for comments on the clinical figure. H.M.M. is supported by the NIHR Great Ormond Street Hospital Biomedical Research Centre (V1299), H2020 Marie Skłodowska-Curie Actions (800556), Ministry of Higher Education of Egypt, UCL Therapeutic Acceleration Support (TAS) Fund (559846), Great Ormond Street Children's Charity (V2217). M.L. is supported by the Fondation pour la Recherche Médicale grant DEQ20120323689 and the Legs Poix grant from the Chancellerie des Universités of Sorbonne Université. We thank RaDiCo, funded by the French National Research Agency under the specific program "Investments for the Future" (Cohort grant agreement ANR-10-COHO0003). We are grateful to all members of Pascal Barbry's team and to the UCAGenomiX and IPMC imaging platforms for fruitful discussions and help in artwork. The work of the team of L-E.Z. is funded by grants from the Conseil Départemental des Alpes Maritimes (2016294DGADSH-CV), la Fondation pour la Recherche Médicale (DEQ20180339158), the Chan Zuckerberg Initiative (Silicon Valley Foundation, 2017-175159-5022), the Agence Nationale de la Recherche (ANR-19-CE14-0027), the Labex Signalife (ANR-11-LABX-0028-01) and the association Vaincre la Mucoviscidose (RF20180502280, RF20180502258). 
Table 1. Genes involved in primary ciliary dyskinesia in humans and corresponding main ciliary ultrastructural phenotype

\begin{tabular}{|c|c|c|c|}
\hline $\begin{array}{l}\text { HGNC gene symbol } \\
\text { (previous name) }\end{array}$ & Chr & $\begin{array}{l}\text { Inheritance } \\
\text { mode }\end{array}$ & Original identification \\
\hline \multicolumn{4}{|c|}{ Absence/truncation of outer dynein arms } \\
\hline ODAD2 (ARMC4) & 10 & AR & Hjeij et al., 2013 [154] \\
\hline ODAD3 (CCDC151) & 19 & AR & Alsaadi et al., 2014 [155]; Hjeij et al., 2014 [156] \\
\hline ODAD1 (CCDC114) & 19 & $\mathrm{AR}$ & Onoufriadis et al., 2013 [136]; Knowles et al., 2013 [157] \\
\hline DNAH5 & 5 & AR & Olbrich et al., $2002[158]$ \\
\hline DNAH9 & 17 & AR & Fassad et al., 2018b [128]; Loges et al., 2018 [127] \\
\hline DNAH11 ${ }^{a}$ & 7 & AR & Bartoloni et al., 2002 [159] \\
\hline DNAl1 & 9 & AR & Pennarun et al., 1999 [151] \\
\hline DNAI2 & 17 & $\mathrm{AR}$ & Loges et al., $2008[160]$ \\
\hline DNAL1 & 14 & AR & Horváth et al., 2005 [161] \\
\hline NME8 (TXNDC3) & 7 & AR & Duriez et al., 2007 [94] \\
\hline TTC25 (ODAD4) & 17 & $\mathrm{AR}$ & Wallmeier et al., 2016 [162] \\
\hline \multicolumn{4}{|c|}{ Absence of outer and inner dynein arms } \\
\hline CCDC103 & 17 & AR & Panizzi et al., 2012 [163] \\
\hline CFAP298 (C21orf59) & 21 & AR & Austin-Tse et al., 2013 [102] \\
\hline CFAP300 (C11orf70) & 11 & AR & Fassad et al., 2018a [109]; Höben et al., 2018 [164] \\
\hline DNAAF1 (LRRC50) & 16 & AR & Duquesnoy et al., 2009 [165]; Loges et al., 2009 [166] \\
\hline DNAAF2 (KTU) & 14 & AR & Omran et al., $2008[96]$ \\
\hline DNAAF3 & 19 & AR & Mitchison et al., $2012[104]$ \\
\hline DNAAF4 (DYX1C1) & 15 & $\mathrm{AR}$ & Tarkar et al., 2013 [167] \\
\hline DNAAF5 (HEATR2) & 7 & AR & Horani et al., 2012 [168] \\
\hline DNAAF6 (PIH1D3) & $\mathrm{X}$ & XLR & Olcese et al., 2017 [86]; Paff et al., 2017 [169] \\
\hline LRRC6 & 8 & $\mathrm{AR}$ & Kott et al., 2012 [170] \\
\hline RPGR & $\mathrm{X}$ & XLR & Moore et al., 2006 [140] \\
\hline SPAG1 & 8 & $\mathrm{AR}$ & Knowles et al., 2013 [171] \\
\hline ZMYND10 & 3 & AR & Moore et al., 2013 [153]; Zariwala et al., 2013 [172] \\
\hline \multicolumn{4}{|c|}{ Axonemal disorganization and absence of inner dynein arms } \\
\hline CCDC39 & 3 & AR & Merveille et al., 2011 [120] \\
\hline CCDC40 & 17 & AR & Becker-Heck et al., 2011 [119] \\
\hline$T T C 12^{b}$ & 11 & AR & Thomas et al., 2020 [107] \\
\hline \multicolumn{4}{|c|}{ Nexin dynein regulatory complex defects } \\
\hline$C C D C 65(D R C 2)^{c}$ & 12 & AR & Horani et al., 2013 [129]; Austin-Tse et al., 2013 [102] \\
\hline$D R C 1 c^{c}$ & 2 & AR & Wirschell et al., $2013[131]$ \\
\hline GAS8 ${ }^{d}$ & 16 & AR & Olbrich et al., 2015 [130] \\
\hline \multicolumn{4}{|c|}{ Central complex defects } \\
\hline CFAP221 ${ }^{e}$ & 2 & AR & Bustamante-Marin et al., 2020 [173] \\
\hline DNAJB13 & 11 & $\mathrm{AR}$ & El Khouri et al., 2016 [174] \\
\hline HYDIN $^{f}$ & 16 & AR & Olbrich et al., 2012 [175] \\
\hline NME5 & 5 & $\mathrm{AR}$ & Cho et al., 2020 [176] \\
\hline RSPH1 & 21 & AR & Kott et al., 2013 [177] \\
\hline RSPH3 & 6 & AR & Jeanson et al., 2015 [178] \\
\hline RSPH4A & 6 & $\mathrm{AR}$ & Castleman et al., 2009 [125] \\
\hline RSPH9 & 6 & AR & Castleman et al., 2009 [125] \\
\hline STK36 & 2 & $\mathrm{AR}$ & Edelbusch et al., 2017 [95] \\
\hline SPEF2 ${ }^{f}$ & 5 & AR & Cindrić et al., 2019 [137] \\
\hline \multicolumn{4}{|l|}{ Normal ultrastructure } \\
\hline CFAP57 $^{9}$ & 1 & AR & Bustamante-Marin et al., 2020 [112] \\
\hline LRRC56 ${ }^{h}$ & 11 & AR & Bonnefoy et al., 2018 [111] \\
\hline GAS2L2 $^{i}$ & 17 & AR & Bustamante-Marin et al., 2019 [113] \\
\hline NEK10 & 3 & AR & Chivukula et al., 2020 [75] \\
\hline OFD1 & $\mathrm{X}$ & $\mathrm{XLR}^{k}$ & Budny et al., 2006 [143]; Bukowy-Bieryllo et al., 2019 [144] \\
\hline \multicolumn{4}{|c|}{ Multiciliogenesis defect } \\
\hline CCNO & 5 & AR & Wallmeier et al., 2014 [73] \\
\hline FOXJ1 & 17 & $\mathrm{AD}$ & Wallmeier et al., 2019 [74] \\
\hline MCIDAS & 5 & $\mathrm{AR}$ & Boon et al., 2014 [72] \\
\hline
\end{tabular}

a, ODA defects visible by high-resolution electron tomography; ${ }^{b}$, mild microtubular disorganization compared to CCDC39/CCDC40, with absent IDA and ODA in patient sperm; c, absent N-DRC links reported in some TEM cilia sections; ${ }^{d}$, mis-aligned outer microtubule doublets in some TEM cilia sections; ${ }^{e}$, no ultrastructure yet recorded in TEM; ${ }^{f}$, central microtubular pair defects that can be missed in TEM structural analysis; g, CFAP57 is axonemal and depletion causes absent IDA in Chlamydomonas; ${ }^{\mathrm{h}}$, LRRC56 is axonemal and depletion causes absence of distal ODAs in Trypanosoma; ${ }^{i}$, cilia orientation affected; ${ }^{j}$, short cilia; ${ }^{k}$, C-terminal mutations associated with XLR PCD whilst other mutations are associated to syndromic ciliopathies with XLD or XLR inheritance. HGNC, Human Gene 
Nomenclature Committee; Chr., chromosome location; AR, autosomal recessive; $A D$, autosomal dominant; XLR, X-linked recessive; XLD, X-linked dominant; MT, microtubule. 


\section{Figure legends}

Figure 1. Molecular atlas of the human airway epithelium.

Top panel, the cellular composition of the trachea and large airways is now well-defined, as contributed to through single-cell RNA-seq studies, with gene markers defined for each cell type (shown in parentheses). Bottom panel, UMAP plot of healthy airway scRNA-seq datasets, including a set of rare cells explained on the right. Distinct cell types are labelled in a specific colour, blue indicates those with multiciliated cell markers i.e. pre-multiciliated (light blue) and multiciliated (dark blue). Based upon data from $[3,149]$.

Figure 2. Motile cilia disease and regulation of airway multiciliogenesis.

The generation of multiciliated cells involves a highly regulated developmental program for secretory-to-ciliated cell conversion which is overseen by two master transcription regulators, GMNC and MCIDAS, under the inhibitory regulatory control of Geminin and Notch. Their induction of multiciliogenesis essential genes (e.g. MYB, CDC20B, FOXJ1, the RFX2 and RFX3 transcription factors and TP73) results in downstream centriole amplification, basal body docking and ciliogenesis which is accompanied by up-regulation of multiple axonemal dyneins and other motile cilia proteins. Mutations in this pathway affecting the transcription regulators MCIDAS and FOXJ1 and the centriole biogenesis regulator CCNO (highlighted in red) cause motile ciliopathies with severe airway disease often accompanied by hydrocephalus. The kinase NEK10, an additional regulator of multiciliogenesis and motile cilia protein expression, is also highlighted red as mutations cause PCD symptoms in patients associated with short cilia but of apparently milder clinical effect.

Figure 3. Clinical features of motile cilia disease and recommended clinical tests to screen for airway cilia defects.

Top panel shows the major features of PCD. Bottom panel, diagnosis of ciliary dyskinesia is made using a range of analyses (blue chevrons), with genetic screening and gene discovery research an important part, with the advent of high throughput and omics-level molecular genomic analyses, in particular to describe the emerging clinical spectrum and non-classic disease variants. $\mathrm{nNO}$, nasal nitric oxide; TEM, transmission election microscopy; IF, immunofluorescence protein analysis; HSVMA, high speed video microscopy analysis to investigate cilia beat frequency, pattern and number. ${ }^{*}$ Range based upon data from [79-81].

Figure 4. Timeline of PCD clinical description, respiratory and ciliary investigations and significant steps in the discovery of its molecular causes. Milestones show the first reported occurrences in the literature, to the best of our knowledge. References are in the main text. CNS, central nervous system; WES, whole exome sequencing; WGS, whole genome sequencing; cryoET, cryo-electron tomography.

Figure 5. Location and function of the proteins encoded by PCD genes.

Shows locations of encoded proteins (red symbols) in human airway ciliated cells, dotted red lines indicate a cross-section through the motile cilium, to show the proteins of the internal 9+2 microtubular array. DA, dynein arms; a, syndromic PCD forms (RPGR implicated in retinitis pigmentosa and/or PCD; OFD1 exon 20 and 21 frameshift mutations implicated in typical PCD and other mutations implicated in syndromic ciliopathies); ${ }^{b}$, proposed functions; ${ }^{c}$, to-date, genetic results so far based upon data from one human family; ${ }^{d}$, not upregulated during ciliogenesis [91].

Figure 6. Differential composition of dynein heavy chains of the outer dynein arms in human respiratory cilia and sperm flagella.

See text for explanation. 


\section{References}

[1] P.A. Reyfman, J.M. Walter, N. Joshi, K.R. Anekalla, A.C. McQuattie-Pimentel, S. Chiu, R. Fernandez, M. Akbarpour, C.I. Chen, Z. Ren, R. Verma, H. Abdala-Valencia, K. Nam, M. Chi, S. Han, F.J. Gonzalez-Gonzalez, S. Soberanes, S. Watanabe, K.J.N. Williams, A.S. Flozak, T.T. Nicholson, V.K. Morgan, D.R. Winter, M. Hinchcliff, C.L. Hrusch, R.D. Guzy, C.A. Bonham, A.I. Sperling, R. Bag, R.B. Hamanaka, G.M. Mutlu, A.V. Yeldandi, S.A. Marshall, A. Shilatifard, L.A.N. Amaral, H. Perlman, J.I. Sznajder, A.C. Argento, C.T. Gillespie, J. Dematte, M. Jain, B.D. Singer, K.M. Ridge, A.P. Lam, A. Bharat, S.M. Bhorade, C.J. Gottardi, G.R.S. Budinger, A.V. Misharin, Single-Cell Transcriptomic Analysis of Human Lung Provides Insights into the Pathobiology of Pulmonary Fibrosis, American journal of respiratory and critical care medicine 199(12) (2019) 1517-1536.

[2] F.A. Vieira Braga, G. Kar, M. Berg, O.A. Carpaij, K. Polanski, L.M. Simon, S. Brouwer, T. Gomes, L. Hesse, J. Jiang, E.S. Fasouli, M. Efremova, R. Vento-Tormo, C. TalaveraLopez, M.R. Jonker, K. Affleck, S. Palit, P.M. Strzelecka, H.V. Firth, K.T. Mahbubani, A. Cvejic, K.B. Meyer, K. Saeb-Parsy, M. Luinge, C.A. Brandsma, W. Timens, I. Angelidis, M. Strunz, G.H. Koppelman, A.J. van Oosterhout, H.B. Schiller, F.J. Theis, M. van den Berge, M.C. Nawijn, S.A. Teichmann, A cellular census of human lungs identifies novel cell states in health and in asthma, Nature medicine 25(7) (2019) 11531163.

[3] M. Deprez, L.E. Zaragosi, M. Truchi, C. Becavin, S. Ruiz Garcia, M.J. Arguel, M. Plaisant, V. Magnone, K. Lebrigand, S. Abelanet, F. Brau, A. Paquet, D. Pe'er, C.H. Marquette, S. Leroy, P. Barbry, A Single-cell Atlas of the Human Healthy Airways, American journal of respiratory and critical care medicine (2020).

[4] K.C. Goldfarbmuren, N.D. Jackson, S.P. Sajuthi, N. Dyjack, K.S. Li, C.L. Rios, E.G. Plender, M.T. Montgomery, J.L. Everman, P.E. Bratcher, E.K. Vladar, M.A. Seibold, Dissecting the cellular specificity of smoking effects and reconstructing lineages in the human airway epithelium, Nat Commun 11(1) (2020) 2485.

[5] D.T. Montoro, A.L. Haber, M. Biton, V. Vinarsky, B. Lin, S.E. Birket, F. Yuan, S. Chen, H.M. Leung, J. Villoria, N. Rogel, G. Burgin, A.M. Tsankov, A. Waghray, M. Slyper, J. Waldman, L. Nguyen, D. Dionne, O. Rozenblatt-Rosen, P.R. Tata, H. Mou, M. Shivaraju, H. Bihler, M. Mense, G.J. Tearney, S.M. Rowe, J.F. Engelhardt, A. Regev, J. Rajagopal, A revised airway epithelial hierarchy includes CFTR-expressing ionocytes, Nature 560(7718) (2018) 319-324.

[6] M.A. Seibold, Interleukin-13 Stimulation Reveals the Cellular and Functional Plasticity of the Airway Epithelium, Annals of the American Thoracic Society 15(Suppl 2) (2018) S98-S102.

[7] S. Ruiz Garcia, M. Deprez, K. Lebrigand, A. Cavard, A. Paquet, M.J. Arguel, V. Magnone, M. Truchi, I. Caballero, S. Leroy, C.H. Marquette, B. Marcet, P. Barbry, L.E. Zaragosi, Novel dynamics of human mucociliary differentiation revealed by single-cell RNA sequencing of nasal epithelial cultures, Development 146(20) (2019).

[8] J.E. Boers, A.W. Ambergen, F.B. Thunnissen, Number and proliferation of basal and parabasal cells in normal human airway epithelium, American journal of respiratory and critical care medicine 157(6 Pt 1) (1998) 2000-6.

[9] J.K. Watson, S. Rulands, A.C. Wilkinson, A. Wuidart, M. Ousset, A. Van Keymeulen, B. Gottgens, C. Blanpain, B.D. Simons, E.L. Rawlins, Clonal Dynamics Reveal Two Distinct Populations of Basal Cells in Slow-Turnover Airway Epithelium, Cell reports 12(1) (2015) 90-101.

[10] M.J. Evans, C.G. Plopper, The role of basal cells in adhesion of columnar epithelium to airway basement membrane, The American review of respiratory disease 138(2) (1988) 481-3.

[11] M.J. Evans, R.A. Cox, S.G. Shami, B. Wilson, C.G. Plopper, The role of basal cells in attachment of columnar cells to the basal lamina of the trachea, American journal of respiratory cell and molecular biology 1 (6) (1989) 463-9. 
[12] E. Shebani, S. Shahana, C. Janson, G.M. Roomans, B.H.R. group, Attachment of columnar airway epithelial cells in asthma, Tissue \& cell 37(2) (2005) 145-52.

[13] M. Mori, J.E. Mahoney, M.R. Stupnikov, J.R. Paez-Cortez, A.D. Szymaniak, X. Varelas, D.B. Herrick, J. Schwob, H. Zhang, W.V. Cardoso, Notch3-Jagged signaling controls the pool of undifferentiated airway progenitors, Development 142(2) (2015) 258-67.

[14] H. Wang, Y. Liu, Z. Liu, Clara cell 10-kD protein in inflammatory upper airway diseases, Curr Opin Allergy Clin Immunol 13(1) (2013) 25-30.

[15] C.H. Hung, L.C. Chen, Z. Zhang, B. Chowdhury, W.L. Lee, B. Plunkett, C.H. Chen, A.C. Myers, S.K. Huang, Regulation of TH2 responses by the pulmonary Clara cell secretory $10-k d$ protein, The Journal of allergy and clinical immunology 114(3) (2004) 664-70.

[16] H. Wang, X.B. Long, P.P. Cao, N. Wang, Y. Liu, Y.H. Cui, S.K. Huang, Z. Liu, Clara cell 10-kD protein suppresses chitinase 3-like 1 expression associated with eosinophilic chronic rhinosinusitis, American journal of respiratory and critical care medicine 181(9) (2010) 908-16.

[17] B.R. Stripp, S.D. Reynolds, Maintenance and repair of the bronchiolar epithelium, Proceedings of the American Thoracic Society 5(3) (2008) 328-33.

[18] D. Lafkas, A. Shelton, C. Chiu, G. de Leon Boenig, Y. Chen, S.S. Stawicki, C. Siltanen, M. Reichelt, M. Zhou, X. Wu, J. Eastham-Anderson, H. Moore, M. Roose-Girma, Y. Chinn, J.Q. Hang, S. Warming, J. Egen, W.P. Lee, C. Austin, Y. Wu, J. Payandeh, J.B. Lowe, C.W. Siebel, Therapeutic antibodies reveal Notch control of transdifferentiation in the adult lung, Nature 528(7580) (2015) 127-31.

[19] R. Bals, D.J. Weiner, J.M. Wilson, The innate immune system in cystic fibrosis lung disease, The Journal of clinical investigation 103(3) (1999) 303-7.

[20] J.H. Widdicombe, J.J. Wine, Airway Gland Structure and Function, Physiological reviews 95(4) (2015) 1241-319.

[21] C. Coraux, R. Hajj, P. Lesimple, E. Puchelle, [Repair and regeneration of the airway epithelium], Med Sci (Paris) 21(12) (2005) 1063-9.

[22] R.G. Breeze, E.B. Wheeldon, The cells of the pulmonary airways, The American review of respiratory disease 116(4) (1977) 705-77.

[23] A. Wanner, M. Salathe, T.G. O'Riordan, Mucociliary clearance in the airways, American journal of respiratory and critical care medicine 154(6 Pt 1) (1996) 1868-902.

[24] M.J. Sanderson, M.A. Sleigh, Serum proteins agglutinate cilia and modify ciliary coordination, Pediatric research 15(3) (1981) 219-28.

[25] E.R. Brooks, J.B. Wallingford, Multiciliated cells, Current biology : CB 24(19) (2014) R973-82.

[26] J.H. Watson, G.L. Brinkman, Electron Microscopy of the Epithelial Cells of Normal and Bronchitic Human Bronchus, The American review of respiratory disease 90 (1964) 851-66.

[27] C. Sauvanet, J. Wayt, T. Pelaseyed, A. Bretscher, Structure, regulation, and functional diversity of microvilli on the apical domain of epithelial cells, Annu Rev Cell Dev Biol 31 (2015) 593-621.

[28] D.R. Revinski, L.E. Zaragosi, C. Boutin, S. Ruiz-Garcia, M. Deprez, V. Thome, O. Rosnet, A.S. Gay, O. Mercey, A. Paquet, N. Pons, G. Ponzio, B. Marcet, L. Kodjabachian, P. Barbry, CDC20B is required for deuterosome-mediated centriole production in multiciliated cells, Nat Commun 9(1) (2018) 4668.

[29] S.P. Sorokin, Reconstructions of centriole formation and ciliogenesis in mammalian lungs, Journal of cell science 3(2) (1968) 207-30.

[30] D.A. Klos Dehring, E.K. Vladar, M.E. Werner, J.W. Mitchell, P. Hwang, B.J. Mitchell, Deuterosome-mediated centriole biogenesis, Developmental cell 27(1) (2013) 103-12.

[31] H. Zhao, L. Zhu, Y. Zhu, J. Cao, S. Li, Q. Huang, T. Xu, X. Huang, X. Yan, X. Zhu, The Cep63 paralogue Deup1 enables massive de novo centriole biogenesis for vertebrate multiciliogenesis, Nature cell biology 15(12) (2013) 1434-44. 
[32] A. Al Jord, A.I. Lemaitre, N. Delgehyr, M. Faucourt, N. Spassky, A. Meunier, Centriole amplification by mother and daughter centrioles differs in multiciliated cells, Nature 516(7529) (2014) 104-7.

[33] H. Zhao, Q. Chen, C. Fang, Q. Huang, J. Zhou, X. Yan, X. Zhu, Parental centrioles are dispensable for deuterosome formation and function during basal body amplification, EMBO reports 20(4) (2019).

[34] O. Mercey, A. Al Jord, P. Rostaing, A. Mahuzier, A. Fortoul, A.R. Boudjema, M. Faucourt, N. Spassky, A. Meunier, Dynamics of centriole amplification in centrosomedepleted brain multiciliated progenitors, Scientific reports 9(1) (2019) 13060.

[35] M. Morimoto, Z. Liu, H.T. Cheng, N. Winters, D. Bader, R. Kopan, Canonical Notch signaling in the developing lung is required for determination of arterial smooth muscle cells and selection of Clara versus ciliated cell fate, Journal of cell science $123(\mathrm{Pt} 2)$ (2010) 213-24.

[36] P.N. Tsao, M. Vasconcelos, K.I. Izvolsky, J. Qian, J. Lu, W.V. Cardoso, Notch signaling controls the balance of ciliated and secretory cell fates in developing airways, Development 136(13) (2009) 2297-307.

[37] A. Pardo-Saganta, P.R. Tata, B.M. Law, B. Saez, R.D. Chow, M. Prabhu, T. Gridley, J. Rajagopal, Parent stem cells can serve as niches for their daughter cells, Nature 523(7562) (2015) 597-601.

[38] J.R. Rock, X. Gao, Y. Xue, S.H. Randell, Y.Y. Kong, B.L. Hogan, Notch-dependent differentiation of adult airway basal stem cells, Cell stem cell 8(6) (2011) 639-48.

[39] M. Arbi, D.E. Pefani, C. Kyrousi, M.E. Lalioti, A. Kalogeropoulou, A.D. Papanastasiou, S. Taraviras, Z. Lygerou, GemC1 controls multiciliogenesis in the airway epithelium, EMBO reports 17(3) (2016) 400-13.

[40] C. Kyrousi, M. Arbi, G.A. Pilz, D.E. Pefani, M.E. Lalioti, J. Ninkovic, M. Gotz, Z. Lygerou, S. Taraviras, Mcidas and GemC1 are key regulators for the generation of multiciliated ependymal cells in the adult neurogenic niche, Development 142(21) (2015) 3661-74.

[41] F. Zhou, V. Narasimhan, M. Shboul, Y.L. Chong, B. Reversade, S. Roy, Gmnc Is a Master Regulator of the Multiciliated Cell Differentiation Program, Current biology : CB 25(24) (2015) 3267-73.

[42] B. Terre, G. Piergiovanni, S. Segura-Bayona, G. Gil-Gomez, S.A. Youssef, C.S. Attolini, M. Wilsch-Brauninger, C. Jung, A.M. Rojas, M. Marjanovic, P.A. Knobel, L.

Palenzuela, T. Lopez-Rovira, S. Forrow, W.B. Huttner, M.A. Valverde, A. de Bruin, V. Costanzo, T.H. Stracker, GEMC1 is a critical regulator of multiciliated cell differentiation, The EMBO journal 35(9) (2016) 942-60.

[43] J.L. Stubbs, E.K. Vladar, J.D. Axelrod, C. Kintner, Multicilin promotes centriole assembly and ciliogenesis during multiciliate cell differentiation, Nature cell biology 14(2) (2012) 140-7.

[44] L. Ma, I. Quigley, H. Omran, C. Kintner, Multicilin drives centriole biogenesis via E2f proteins, Genes \& development 28(13) (2014) 1461-71.

[45] P.S. Danielian, C.F. Bender Kim, A.M. Caron, E. Vasile, R.T. Bronson, J.A. Lees, E2f4 is required for normal development of the airway epithelium, Developmental biology 305(2) (2007) 564-76.

[46] P.S. Danielian, R.A. Hess, J.A. Lees, E2f4 and E2f5 are essential for the development of the male reproductive system, Cell cycle 15(2) (2016) 250-60.

[47] C.B. Marshall, D.J. Mays, J.S. Beeler, J.M. Rosenbluth, K.L. Boyd, G.L. Santos Guasch, T.M. Shaver, L.J. Tang, Q. Liu, Y. Shyr, B.J. Venters, M.A. Magnuson, J.A. Pietenpol, p73 Is Required for Multiciliogenesis and Regulates the Foxj1-Associated Gene Network, Cell reports 14(10) (2016) 2289-300.

[48] A. Nemajerova, D. Kramer, S.S. Siller, C. Herr, O. Shomroni, T. Pena, C. Gallinas Suazo, K. Glaser, M. Wildung, H. Steffen, A. Sriraman, F. Oberle, M. Wienken, M. Hennion, R. Vidal, B. Royen, M. Alevra, D. Schild, R. Bals, J. Donitz, D. Riedel, S. Bonn, K. Takemaru, U.M. Moll, M. Lize, TAp73 is a central transcriptional regulator of airway multiciliogenesis, Genes \& development 30(11) (2016) 1300-12. 
[49] S.L. Brody, X.H. Yan, M.K. Wuerffel, S.K. Song, S.D. Shapiro, Ciliogenesis and left-right axis defects in forkhead factor HFH-4-null mice, American journal of respiratory cell and molecular biology 23(1) (2000) 45-51.

[50] E.N. Blatt, X.H. Yan, M.K. Wuerffel, D.L. Hamilos, S.L. Brody, Forkhead transcription factor HFH-4 expression is temporally related to ciliogenesis, American journal of respiratory cell and molecular biology 21(2) (1999) 168-76.

[51] J.W. Tichelaar, S.E. Wert, R.H. Costa, S. Kimura, J.A. Whitsett, HNF-3/forkhead homologue-4 (HFH-4) is expressed in ciliated epithelial cells in the developing mouse lung, The journal of histochemistry and cytochemistry : official journal of the Histochemistry Society 47(6) (1999) 823-32.

[52] J. Chen, H.J. Knowles, J.L. Hebert, B.P. Hackett, Mutation of the mouse hepatocyte nuclear factor/forkhead homologue 4 gene results in an absence of cilia and random left-right asymmetry, The Journal of clinical investigation 102(6) (1998) 1077-82.

[53] Y. You, T. Huang, E.J. Richer, J.E. Schmidt, J. Zabner, Z. Borok, S.L. Brody, Role of fbox factor foxj 1 in differentiation of ciliated airway epithelial cells, American journal of physiology. Lung cellular and molecular physiology 286(4) (2004) L650-7.

[54] J. Thomas, L. Morle, F. Soulavie, A. Laurencon, S. Sagnol, B. Durand, Transcriptional control of genes involved in ciliogenesis: a first step in making cilia, Biology of the cell 102(9) (2010) 499-513.

[55] X. Yu, C.P. Ng, H. Habacher, S. Roy, Foxj1 transcription factors are master regulators of the motile ciliogenic program, Nature genetics 40(12) (2008) 1445-53.

[56] E.P. Campbell, I.K. Quigley, C. Kintner, Foxn4 promotes gene expression required for the formation of multiple motile cilia, Development 143(24) (2016) 4654-4664.

[57] M. Xiang, S. Li, Foxn4: a multi-faceted transcriptional regulator of cell fates in vertebrate development, Sci China Life Sci 56(11) (2013) 985-93.

[58] S.P. Choksi, G. Lauter, P. Swoboda, S. Roy, Switching on cilia: transcriptional networks regulating ciliogenesis, Development 141(7) (2014) 1427-41.

[59] L. El Zein, A. Ait-Lounis, L. Morle, J. Thomas, B. Chhin, N. Spassky, W. Reith, B. Durand, RFX3 governs growth and beating efficiency of motile cilia in mouse and controls the expression of genes involved in human ciliopathies, Journal of cell science 122(Pt 17) (2009) 3180-9.

[60] M.I. Chung, S.M. Peyrot, S. LeBoeuf, T.J. Park, K.L. McGary, E.M. Marcotte, J.B. Wallingford, RFX2 is broadly required for ciliogenesis during vertebrate development, Developmental biology 363(1) (2012) 155-65.

[61] L. Didon, R.K. Zwick, I.W. Chao, M.S. Walters, R. Wang, N.R. Hackett, R.G. Crystal, RFX3 modulation of FOXJ1 regulation of cilia genes in the human airway epithelium, Respiratory research 14 (2013) 70.

[62] B. Marcet, B. Chevalier, G. Luxardi, C. Coraux, L.E. Zaragosi, M. Cibois, K. RobbeSermesant, T. Jolly, B. Cardinaud, C. Moreilhon, L. Giovannini-Chami, B. NawrockiRaby, P. Birembaut, R. Waldmann, L. Kodjabachian, P. Barbry, Control of vertebrate multiciliogenesis by miR-449 through direct repression of the Delta/Notch pathway, Nature cell biology 13(6) (2011) 693-9.

[63] S. Yuan, C. Tang, Y. Zhang, J. Wu, J. Bao, H. Zheng, C. Xu, W. Yan, mir-34b/c and mir$449 \mathrm{a} / \mathrm{b} / \mathrm{c}$ are required for spermatogenesis, but not for the first cleavage division in mice, Biology open 4(2) (2015) 212-23.

[64] E. Quandt, M.P.C. Ribeiro, J. Clotet, Atypical cyclins: the extended family portrait, Cellular and molecular life sciences: CMLS 77(2) (2020) 231-242.

[65] M.C. Funk, A.N. Bera, T. Menchen, G. Kuales, K. Thriene, S.S. Lienkamp, J. Dengjel, H. Omran, M. Frank, S.J. Arnold, Cyclin O (Ccno) functions during deuterosomemediated centriole amplification of multiciliated cells, The EMBO journal 34(8) (2015) 1078-89.

[66] A. Meunier, J. Azimzadeh, Multiciliated Cells in Animals, Cold Spring Harb Perspect Biol 8(12) (2016).

[67] R.C. Boucher, Muco-Obstructive Lung Diseases, N Engl J Med 380(20) (2019) 1941 1953. 
[68] T. Piorunek, A. Marszalek, W. Biczysko, J. Gozdzik, S. Cofta, M. Seget, Correlation between the stage of cystic fibrosis and the level of morphological changes in adult patients, Journal of physiology and pharmacology : an official journal of the Polish Physiological Society 59 Suppl 6 (2008) 565-72.

[69] H.M. Mitchison, A. Shoemark, Motile cilia defects in diseases other than primary ciliary dyskinesia: The contemporary diagnostic and research role for transmission electron microscopy, Ultrastruct Pathol 41(6) (2017) 415-427.

[70] L.W. Plasschaert, R. Zilionis, R. Choo-Wing, V. Savova, J. Knehr, G. Roma, A.M. Klein, A.B. Jaffe, A single-cell atlas of the airway epithelium reveals the CFTR-rich pulmonary ionocyte, Nature 560(7718) (2018) 377-381.

[71] B.J. Gerovac, N.L. Fregien, IL-13 Inhibits Multicilin Expression and Ciliogenesis via Janus Kinase/Signal Transducer and Activator of Transcription Independently of Notch Cleavage, American journal of respiratory cell and molecular biology 54(4) (2016) 55461.

[72] M. Boon, J. Wallmeier, L. Ma, N.T. Loges, M. Jaspers, H. Olbrich, G.W. Dougherty, J. Raidt, C. Werner, I. Amirav, A. Hevroni, R. Abitbul, A. Avital, R. Soferman, M. Wessels, C. O'Callaghan, E.M. Chung, A. Rutman, R.A. Hirst, E. Moya, H.M. Mitchison, S. Van Daele, K. De Boeck, M. Jorissen, C. Kintner, H. Cuppens, H. Omran, MCIDAS mutations result in a mucociliary clearance disorder with reduced generation of multiple motile cilia, Nat Commun 5 (2014) 4418.

[73] J. Wallmeier, D.A. Al-Mutairi, C.T. Chen, N.T. Loges, P. Pennekamp, T. Menchen, L. Ma, H.E. Shamseldin, H. Olbrich, G.W. Dougherty, C. Werner, B.H. Alsabah, G. Kohler, M. Jaspers, M. Boon, M. Griese, S. Schmitt-Grohe, T. Zimmermann, C. Koerner-Rettberg, E. Horak, C. Kintner, F.S. Alkuraya, H. Omran, Mutations in CCNO result in congenital mucociliary clearance disorder with reduced generation of multiple motile cilia, Nature genetics 46(6) (2014) 646-51.

[74] J. Wallmeier, D. Frank, A. Shoemark, T. Nothe-Menchen, S. Cindric, H. Olbrich, N.T. Loges, I. Aprea, G.W. Dougherty, P. Pennekamp, T. Kaiser, H.M. Mitchison, C. Hogg, S.B. Carr, M.A. Zariwala, T. Ferkol, M.W. Leigh, S.D. Davis, J. Atkinson, S.K. Dutcher, M.R. Knowles, H. Thiele, J. Altmuller, H. Krenz, M. Woste, A. Brentrup, F. Ahrens, C. Vogelberg, D.J. Morris-Rosendahl, H. Omran, De Novo Mutations in FOXJ1 Result in a Motile Ciliopathy with Hydrocephalus and Randomization of Left/Right Body Asymmetry, Am J Hum Genet 105(5) (2019) 1030-1039.

[75] R.R. Chivukula, D.T. Montoro, H.M. Leung, J. Yang, H.E. Shamseldin, M.S. Taylor, G.W. Dougherty, M.A. Zariwala, J. Carson, M.L.A. Daniels, P.R. Sears, K.E. Black, L.P. Hariri, I. Almogarri, E.M. Frenkel, V. Vinarsky, H. Omran, M.R. Knowles, G.J. Tearney, F.S. Alkuraya, D.M. Sabatini, A human ciliopathy reveals essential functions for NEK10 in airway mucociliary clearance, Nature medicine 26(2) (2020) 244-251.

[76] J.S. Lucas, A. Burgess, H.M. Mitchison, E. Moya, M. Williamson, C. Hogg, U.K. National Pcd Service, Diagnosis and management of primary ciliary dyskinesia, Archives of disease in childhood 99(9) (2014) 850-6.

[77] S. Nonaka, Y. Tanaka, Y. Okada, S. Takeda, A. Harada, Y. Kanai, M. Kido, N. Hirokawa, Randomization of left-right asymmetry due to loss of nodal cilia generating leftward flow of extraembryonic fluid in mice lacking KIF3B motor protein, Cell 95(6) (1998) 829-37.

[78] P. Pennekamp, T. Menchen, B. Dworniczak, H. Hamada, Situs inversus and ciliary abnormalities: 20 years later, what is the connection?, Cilia 4(1) (2015) 1.

[79] S. Best, A. Shoemark, B. Rubbo, M.P. Patel, M.R. Fassad, M. Dixon, A.V. Rogers, R.A. Hirst, A. Rutman, S. Ollosson, C.L. Jackson, P. Goggin, S. Thomas, R. Pengelly, T. Cullup, E. Pissaridou, J. Hayward, A. Onoufriadis, C. O'Callaghan, M.R. Loebinger, R. Wilson, E.M. Chung, P. Kenia, V.L. Doughty, J.S. Carvalho, J.S. Lucas, H.M. Mitchison, C. Hogg, Risk factors for situs defects and congenital heart disease in primary ciliary dyskinesia, Thorax 74(2) (2019) 203-205.

[80] A.J. Shapiro, S.D. Davis, T. Ferkol, S.D. Dell, M. Rosenfeld, K.N. Olivier, S.D. Sagel, C. Milla, M.A. Zariwala, W. Wolf, J.L. Carson, M.J. Hazucha, K. Burns, B. Robinson, M.R. 
Knowles, M.W. Leigh, C. Genetic Disorders of Mucociliary Clearance, Laterality defects other than situs inversus totalis in primary ciliary dyskinesia: insights into situs ambiguus and heterotaxy, Chest 146(5) (2014) 1176-1186.

[81] M.P. Kennedy, H. Omran, M.W. Leigh, S. Dell, L. Morgan, P.L. Molina, B.V. Robinson, S.L. Minnix, H. Olbrich, T. Severin, P. Ahrens, L. Lange, H.N. Morillas, P.G. Noone, M.A. Zariwala, M.R. Knowles, Congenital heart disease and other heterotaxic defects in a large cohort of patients with primary ciliary dyskinesia, Circulation 115(22) (2007) 2814-21.

[82] B. Rubbo, J.S. Lucas, Clinical care for primary ciliary dyskinesia: current challenges and future directions, European respiratory review : an official journal of the European Respiratory Society 26(145) (2017).

[83] J.S. Lucas, A. Barbato, S.A. Collins, M. Goutaki, L. Behan, D. Caudri, S. Dell, E. Eber, E. Escudier, R.A. Hirst, C. Hogg, M. Jorissen, P. Latzin, M. Legendre, M.W. Leigh, F. Midulla, K.G. Nielsen, H. Omran, J.F. Papon, P. Pohunek, B. Redfern, D. Rigau, B. Rindlisbacher, F. Santamaria, A. Shoemark, D. Snijders, T. Tonia, A. Titieni, W.T. Walker, C. Werner, A. Bush, C.E. Kuehni, European Respiratory Society guidelines for the diagnosis of primary ciliary dyskinesia, Eur Respir J 49(1) (2017).

[84] A. Shoemark, S. Dell, A. Shapiro, J.S. Lucas, ERS and ATS diagnostic guidelines for primary ciliary dyskinesia: similarities and differences in approach to diagnosis, Eur Respir J 54(3) (2019).

[85] M.R. Fassad, M.P. Patel, A. Shoemark, T. Cullup, J. Hayward, M. Dixon, A.V. Rogers, S. Ollosson, C. Jackson, P. Goggin, R.A. Hirst, A. Rutman, J. Thompson, L. Jenkins, P. Aurora, E. Moya, P. Chetcuti, C. O'Callaghan, D.J. Morris-Rosendahl, C.M. Watson, R. Wilson, S. Carr, W. Walker, A. Pitno, S. Lopes, H. Morsy, W. Shoman, L. Pereira, C. Constant, M.R. Loebinger, E.M.K. Chung, P. Kenia, N. Rumman, N. Fasseeh, J.S. Lucas, C. Hogg, H.M. Mitchison, Clinical utility of NGS diagnosis and disease stratification in a multiethnic primary ciliary dyskinesia cohort, Journal of medical genetics 57(5) (2020) 322-330.

[86] C. Olcese, M.P. Patel, A. Shoemark, S. Kiviluoto, M. Legendre, H.J. Williams, C.K. Vaughan, J. Hayward, A. Goldenberg, R.D. Emes, M.M. Munye, L. Dyer, T. Cahill, J. Bevillard, C. Gehrig, M. Guipponi, S. Chantot, P. Duquesnoy, L. Thomas, L. Jeanson, B. Copin, A. Tamalet, C. Thauvin-Robinet, J.F. Papon, A. Garin, I. Pin, G. Vera, P. Aurora, M.R. Fassad, L. Jenkins, C. Boustred, T. Cullup, M. Dixon, A. Onoufriadis, A. Bush, E.M. Chung, S.E. Antonarakis, M.R. Loebinger, R. Wilson, M. Armengot, E. Escudier, C. Hogg, U.K.R. Group, S. Amselem, Z. Sun, L. Bartoloni, J.L. Blouin, H.M. Mitchison, X-linked primary ciliary dyskinesia due to mutations in the cytoplasmic axonemal dynein assembly factor PIH1D3, Nat Commun 8 (2017) 14279.

[87] J.T. den Dunnen, S.E. Antonarakis, Nomenclature for the description of human sequence variations, Human genetics 109(1) (2001) 121-4.

[88] S. Richards, N. Aziz, S. Bale, D. Bick, S. Das, J. Gastier-Foster, W.W. Grody, M. Hegde, E. Lyon, E. Spector, K. Voelkerding, H.L. Rehm, A.L.Q.A. Committee, Standards and guidelines for the interpretation of sequence variants: a joint consensus recommendation of the American College of Medical Genetics and Genomics and the Association for Molecular Pathology, Genetics in medicine : official journal of the American College of Medical Genetics 17(5) (2015) 405-24.

[89] C.R. Marshall, S.W. Scherer, M.A. Zariwala, L. Lau, T.A. Paton, T. Stockley, R.K. Jobling, P.N. Ray, M.R. Knowles, F.C. Consortium, D.A. Hall, S.D. Dell, R.H. Kim, Whole-Exome Sequencing and Targeted Copy Number Analysis in Primary Ciliary Dyskinesia, G3 5(8) (2015) 1775-81.

[90] H.E. Shamseldin, I. Al Mogarri, M.M. Alqwaiee, A.S. Alharbi, K. Baqais, M. AlSaadi, T. AlAnzi, A. Alhashem, A. Saghier, W. Ameen, N. Ibrahim, J. Yang, F. Abdulwahab, M. Hashem, R.R. Chivukula, F.S. Alkuraya, An exome-first approach to aid in the diagnosis of primary ciliary dyskinesia, Human genetics (2020).

[91] T. Paff, I.E. Kooi, Y. Moutaouakil, E. Riesebos, E.A. Sistermans, H. Daniels, J.M.M. Weiss, H. Niessen, E.G. Haarman, G. Pals, D. Micha, Diagnostic yield of a targeted 
gene panel in primary ciliary dyskinesia patients, Human mutation 39(5) (2018) 653665.

[92] A. Shoemark, E. Moya, R.A. Hirst, M.P. Patel, E.A. Robson, J. Hayward, J. Scully, M.R. Fassad, W. Lamb, M. Schmidts, M. Dixon, R.S. Patel-King, A.V. Rogers, A. Rutman, C.L. Jackson, P. Goggin, B. Rubbo, S. Ollosson, S. Carr, W. Walker, B. Adler, M.R. Loebinger, R. Wilson, A. Bush, H. Williams, C. Boustred, L. Jenkins, E. Sheridan, E.M.K. Chung, C.M. Watson, T. Cullup, J.S. Lucas, P. Kenia, C. O'Callaghan, S.M. King, C. Hogg, H.M. Mitchison, High prevalence of CCDC103 p.His154Pro mutation causing primary ciliary dyskinesia disrupts protein oligomerisation and is associated with normal diagnostic investigations, Thorax 73(2) (2018) 157-166.

[93] R. Mani, S. Belkacem, Z. Soua, S. Chantot, G. Montantin, S. Tissier, B. Copin, J. Bouguila, N. Rive Le Gouard, L. Boughamoura, S. Ben Ameur, M. Hachicha, R. Boussoffara, K. Boussetta, S. Hammouda, A. Bedoui, H. Besbes, S. Meddeb, K. Chraeit, M. Khlifa, E. Escudier, S. Amselem, I. Mabrouk, M. Legendre, Primary ciliary dyskinesia gene contribution in Tunisia: Identification of a major Mediterranean allele, Human mutation 41(1) (2020) 115-121.

[94] B. Duriez, P. Duquesnoy, E. Escudier, A.M. Bridoux, D. Escalier, I. Rayet, E. Marcos, A.M. Vojtek, J.F. Bercher, S. Amselem, A common variant in combination with a nonsense mutation in a member of the thioredoxin family causes primary ciliary dyskinesia, Proceedings of the National Academy of Sciences of the United States of America 104(9) (2007) 3336-41.

[95] C. Edelbusch, S. Cindric, G.W. Dougherty, N.T. Loges, H. Olbrich, J. Rivlin, J. Wallmeier, P. Pennekamp, I. Amirav, H. Omran, Mutation of serine/threonine protein kinase 36 (STK36) causes primary ciliary dyskinesia with a central pair defect, Human mutation 38(8) (2017) 964-969.

[96] H. Omran, D. Kobayashi, H. Olbrich, T. Tsukahara, N.T. Loges, H. Hagiwara, Q. Zhang, G. Leblond, E. O'Toole, C. Hara, H. Mizuno, H. Kawano, M. Fliegauf, T. Yagi, S. Koshida, A. Miyawaki, H. Zentgraf, H. Seithe, R. Reinhardt, Y. Watanabe, R. Kamiya, D.R. Mitchell, H. Takeda, Ktu/PF13 is required for cytoplasmic pre-assembly of axonemal dyneins, Nature 456(7222) (2008) 611-6.

[97] Y. Kakihara, W.A. Houry, The R2TP complex: discovery and functions, Biochim Biophys Acta 1823(1) (2012) 101-7.

[98] C. Maurizy, M. Quinternet, Y. Abel, C. Verheggen, P.E. Santo, M. Bourguet, C.F.P. A, B. Bragantini, M.E. Chagot, M.C. Robert, C. Abeza, P. Fabre, P. Fort, F. Vandermoere, M.F.S. P, J.C. Rain, B. Charpentier, S. Cianferani, T.M. Bandeiras, B. Pradet-Balade, X. Manival, E. Bertrand, The RPAP3-Cterminal domain identifies R2TP-like quaternary chaperones, Nat Commun 9(1) (2018) 2093.

[99] L. Zhao, S. Yuan, Y. Cao, S. Kallakuri, Y. Li, N. Kishimoto, L. DiBella, Z. Sun, Reptin/Ruvbl2 is a Lrrc6/Seahorse interactor essential for cilia motility, Proceedings of the National Academy of Sciences of the United States of America 110(31) (2013) 12697-702.

[100] G.R. Mali, P.L. Yeyati, S. Mizuno, D.O. Dodd, P.A. Tennant, M.A. Keighren, P. Zur Lage, A. Shoemark, A. Garcia-Munoz, A. Shimada, H. Takeda, F. Edlich, S.

Takahashi, A. von Kreigsheim, A.P. Jarman, P. Mill, ZMYND10 functions in a chaperone relay during axonemal dynein assembly, eLife 7 (2018).

[101] R.L. Huizar, C. Lee, A.A. Boulgakov, A. Horani, F. Tu, E.M. Marcotte, S.L. Brody, J.B. Wallingford, A liquid-like organelle at the root of motile ciliopathy, eLife 7 (2018).

[102] C. Austin-Tse, J. Halbritter, M.A. Zariwala, R.M. Gilberti, H.Y. Gee, N. Hellman, N. Pathak, Y. Liu, J.R. Panizzi, R.S. Patel-King, D. Tritschler, R. Bower, E. O'Toole, J.D. Porath, T.W. Hurd, M. Chaki, K.A. Diaz, S. Kohl, S. Lovric, D.Y. Hwang, D.A. Braun, M. Schueler, R. Airik, E.A. Otto, M.W. Leigh, P.G. Noone, J.L. Carson, S.D. Davis, J.E. Pittman, T.W. Ferkol, J.J. Atkinson, K.N. Olivier, S.D. Sagel, S.D. Dell, M. Rosenfeld, C.E. Milla, N.T. Loges, H. Omran, M.E. Porter, S.M. King, M.R. Knowles, I.A. Drummond, F. Hildebrandt, Zebrafish Ciliopathy Screen Plus Human Mutational 
Analysis Identifies C21orf59 and CCDC65 Defects as Causing Primary Ciliary Dyskinesia, Am J Hum Genet 93(4) (2013) 672-86.

[103] C.P. Diggle, D.J. Moore, G. Mali, P. zur Lage, A. Ait-Lounis, M. Schmidts, A. Shoemark, A. Garcia Munoz, M.R. Halachev, P. Gautier, P.L. Yeyati, D.T. Bonthron, I.M. Carr, B. Hayward, A.F. Markham, J.E. Hope, A. von Kriegsheim, H.M. Mitchison, I.J. Jackson, B. Durand, W. Reith, E. Sheridan, A.P. Jarman, P. Mill, HEATR2 plays a conserved role in assembly of the ciliary motile apparatus, PLoS Genet 10(9) (2014) e1004577.

[104] H.M. Mitchison, M. Schmidts, N.T. Loges, J. Freshour, A. Dritsoula, R.A. Hirst, C. O'Callaghan, H. Blau, M. Al Dabbagh, H. Olbrich, P.L. Beales, T. Yagi, H. Mussaffi, E.M. Chung, H. Omran, D.R. Mitchell, Mutations in axonemal dynein assembly factor DNAAF3 cause primary ciliary dyskinesia, Nature genetics 44(4) (2012) 381-9, S1-2.

[105] A. Oltean, A.J. Schaffer, P.V. Bayly, S.L. Brody, Quantifying Ciliary Dynamics during Assembly Reveals Stepwise Waveform Maturation in Airway Cells, American journal of respiratory cell and molecular biology 59(4) (2018) 511-522.

[106] A. Horani, A. Ustione, T. Huang, A.L. Firth, J. Pan, S.P. Gunsten, J.A. Haspel, D.W. Piston, S.L. Brody, Establishment of the early cilia preassembly protein complex during motile ciliogenesis, Proceedings of the National Academy of Sciences of the United States of America 115(6) (2018) E1221-E1228.

[107] L. Thomas, K. Bouhouche, M. Whitfield, G. Thouvenin, A. Coste, B. Louis, C. Szymanski, E. Bequignon, J.F. Papon, M. Castelli, M. Lemullois, X. Dhalluin, V. Drouin-Garraud, G. Montantin, S. Tissier, P. Duquesnoy, B. Copin, F. Dastot, S. Couvet, A.L. Barbotin, C. Faucon, I. Honore, B. Maitre, N. Beydon, A. Tamalet, N. Rives, F. Koll, E. Escudier, A.M. Tassin, A. Toure, V. Mitchell, S. Amselem, M. Legendre, TTC12 Loss-of-Function Mutations Cause Primary Ciliary Dyskinesia and Unveil Distinct Dynein Assembly Mechanisms in Motile Cilia Versus Flagella, Am J Hum Genet 106(2) (2020) 153-169.

[108] M. Taschner, A. Mourao, M. Awasthi, J. Basquin, E. Lorentzen, Structural basis of outer dynein arm intraflagellar transport by the transport adaptor protein ODA16 and the intraflagellar transport protein IFT46, J Biol Chem 292(18) (2017) 7462-7473.

[109] M.R. Fassad, A. Shoemark, P. le Borgne, F. Koll, M. Patel, M. Dixon, J. Hayward, C. Richardson, E. Frost, L. Jenkins, T. Cullup, E.M.K. Chung, M. Lemullois, A. AubussonFleury, C. Hogg, D.R. Mitchell, A.M. Tassin, H.M. Mitchison, C11orf70 Mutations Disrupting the Intraflagellar Transport-Dependent Assembly of Multiple Axonemal Dyneins Cause Primary Ciliary Dyskinesia, Am J Hum Genet 102(5) (2018) 956-972.

[110] V.L. Hartill, G. van de Hoek, M.P. Patel, R. Little, C.M. Watson, I.R. Berry, A. Shoemark, D. Abdelmottaleb, E. Parkes, C. Bacchelli, K. Szymanska, N.V. Knoers, P.J. Scambler, M. Ueffing, K. Boldt, R. Yates, P.J. Winyard, B. Adler, E. Moya, L. Hattingh, A. Shenoy, C. Hogg, E. Sheridan, R. Roepman, D. Norris, H.M. Mitchison, R.H. Giles, C.A. Johnson, DNAAF1 links heart laterality with the AAA+ ATPase RUVBL1 and ciliary intraflagellar transport, Hum Mol Genet 27(3) (2018) 529-545.

[111] S. Bonnefoy, C.M. Watson, K.D. Kernohan, M. Lemos, S. Hutchinson, J.A. Poulter, L.A. Crinnion, I. Berry, J. Simmonds, P. Vasudevan, C. O'Callaghan, R.A. Hirst, A. Rutman, L. Huang, T. Hartley, D. Grynspan, E. Moya, C. Li, I.M. Carr, D.T. Bonthron, M. Leroux, C. Care4Rare Canada, K.M. Boycott, P. Bastin, E.G. Sheridan, Biallelic Mutations in LRRC56, Encoding a Protein Associated with Intraflagellar Transport, Cause Mucociliary Clearance and Laterality Defects, Am J Hum Genet 103(5) (2018) 727-739.

[112] X.M. Bustamante-Marin, A. Horani, M. Stoyanova, W.L. Charng, M. Bottier, P.R. Sears, W.N. Yin, L.A. Daniels, H. Bowen, D.F. Conrad, M.R. Knowles, L.E. Ostrowski, M.A. Zariwala, S.K. Dutcher, Mutation of CFAP57, a protein required for the asymmetric targeting of a subset of inner dynein arms in Chlamydomonas, causes primary ciliary dyskinesia, PLoS Genet 16(8) (2020) e1008691.

[113] X.M. Bustamante-Marin, W.N. Yin, P.R. Sears, M.E. Werner, E.J. Brotslaw, B.J. Mitchell, C.M. Jania, K.L. Zeman, T.D. Rogers, L.E. Herring, L. Refabert, L. Thomas, 
S. Amselem, E. Escudier, M. Legendre, B.R. Grubb, M.R. Knowles, M.A. Zariwala, L.E. Ostrowski, Lack of GAS2L2 Causes PCD by Impairing Cilia Orientation and Mucociliary Clearance, Am J Hum Genet 104(2) (2019) 229-245.

[114] M.A. Chilvers, A. Rutman, C. O'Callaghan, Ciliary beat pattern is associated with specific ultrastructural defects in primary ciliary dyskinesia, The Journal of allergy and clinical immunology 112(3) (2003) 518-24.

[115] S. Blanchon, M. Legendre, M. Bottier, A. Tamalet, G. Montantin, N. Collot, C. Faucon, F. Dastot, B. Copin, A. Clement, M. Filoche, A. Coste, S. Amselem, E. Escudier, J.F. Papon, B. Louis, Deep phenotyping, including quantitative ciliary beating parameters, and extensive genotyping in primary ciliary dyskinesia, Journal of medical genetics 57(4) (2020) 237-244.

[116] A. Shoemark, M. Boon, C. Brochhausen, Z. Bukowy-Bieryllo, M.M. De Santi, P. Goggin, P. Griffin, R.G. Hegele, R.A. Hirst, M.W. Leigh, A. Lupton, K. MacKenney, H. Omran, J.C. Pache, A. Pinto, F.P. Reinholt, J. Schroeder, P. Yiallouros, E. Escudier, B.-P.C.D.N.G.D.G. representing the, International consensus guideline for reporting transmission electron microscopy results in the diagnosis of primary ciliary dyskinesia (BEAT PCD TEM Criteria), Eur Respir J 55(4) (2020).

[117] A. Shoemark, T. Burgoyne, R. Kwan, M. Dixon, M.P. Patel, A.V. Rogers, A. Onoufriadis, J. Scully, F. Daudvohra, T. Cullup, M.R. Loebinger, R. Wilson, E.M.K. Chung, A. Bush, H.M. Mitchison, C. Hogg, Primary ciliary dyskinesia with normal ultrastructure: three-dimensional tomography detects absence of DNAH11, Eur Respir J 51(2) (2018).

[118] D. Antony, A. Becker-Heck, M.A. Zariwala, M. Schmidts, A. Onoufriadis, M. Forouhan, R. Wilson, T. Taylor-Cox, A. Dewar, C. Jackson, P. Goggin, N.T. Loges, H. Olbrich, M. Jaspers, M. Jorissen, M.W. Leigh, W.E. Wolf, M.L. Daniels, P.G. Noone, T.W. Ferkol, S.D. Sagel, M. Rosenfeld, A. Rutman, A. Dixit, C. O'Callaghan, J.S. Lucas, C. Hogg, P.J. Scambler, R.D. Emes, Uk10k, E.M. Chung, A. Shoemark, M.R. Knowles, H. Omran, H.M. Mitchison, Mutations in CCDC39 and CCDC40 are the major cause of primary ciliary dyskinesia with axonemal disorganization and absent inner dynein arms, Human mutation 34(3) (2013) 462-72.

[119] A. Becker-Heck, I.E. Zohn, N. Okabe, A. Pollock, K.B. Lenhart, J. Sullivan-Brown, J. McSheene, N.T. Loges, H. Olbrich, K. Haeffner, M. Fliegauf, J. Horvath, R. Reinhardt, K.G. Nielsen, J.K. Marthin, G. Baktai, K.V. Anderson, R. Geisler, L. Niswander, H. Omran, R.D. Burdine, The coiled-coil domain containing protein CCDC40 is essential for motile cilia function and left-right axis formation, Nature genetics 43(1) (2011) 7984.

[120] A.C. Merveille, E.E. Davis, A. Becker-Heck, M. Legendre, I. Amirav, G. Bataille, J. Belmont, N. Beydon, F. Billen, A. Clement, C. Clercx, A. Coste, R. Crosbie, J. de Blic, S. Deleuze, P. Duquesnoy, D. Escalier, E. Escudier, M. Fliegauf, J. Horvath, K. Hill, M. Jorissen, J. Just, A. Kispert, M. Lathrop, N.T. Loges, J.K. Marthin, Y. Momozawa, G. Montantin, K.G. Nielsen, H. Olbrich, J.F. Papon, I. Rayet, G. Roger, M. Schmidts, H. Tenreiro, J.A. Towbin, D. Zelenika, H. Zentgraf, M. Georges, A.S. Lequarre, N. Katsanis, H. Omran, S. Amselem, CCDC39 is required for assembly of inner dynein arms and the dynein regulatory complex and for normal ciliary motility in humans and dogs, Nature genetics 43(1) (2011) 72-8.

[121] S.D. Davis, M. Rosenfeld, H.S. Lee, T.W. Ferkol, S.D. Sagel, S.D. Dell, C. Milla, J.E. Pittman, A.J. Shapiro, K.M. Sullivan, K.R. Nykamp, J.P. Krischer, M.A. Zariwala, M.R. Knowles, M.W. Leigh, Primary Ciliary Dyskinesia: Longitudinal Study of Lung Disease by Ultrastructure Defect and Genotype, American journal of respiratory and critical care medicine 199(2) (2019) 190-198.

[122] M. Ma, M. Stoyanova, G. Rademacher, S.K. Dutcher, A. Brown, R. Zhang, Structure of the Decorated Ciliary Doublet Microtubule, Cell 179(4) (2019) 909-922 e12.

[123] A. Ta-Shma, R. Hjeij, Z. Perles, G.W. Dougherty, I. Abu Zahira, S.J.F. Letteboer, D. Antony, A. Darwish, D.A. Mans, S. Spittler, C. Edelbusch, S. Cindric, T. NotheMenchen, H. Olbrich, F. Stuhlmann, I. Aprea, P. Pennekamp, N.T. Loges, O. Breuer, 
A. Shaag, A. Rein, E.Y. Gulec, A. Gezdirici, R. Abitbul, N. Elias, I. Amirav, M. Schmidts, R. Roepman, O. Elpeleg, H. Omran, Homozygous loss-of-function mutations in MNS1 cause laterality defects and likely male infertility, PLoS Genet 14(8) (2018) e1007602.

[124] O. Reish, L. Aspit, A. Zouella, Y. Roth, S. Polak-Charcon, T. Baboushkin, L. Benyamini, T.E. Scheetz, H. Mussaffi, V.C. Sheffield, R. Parvari, A Homozygous Nme7 Mutation Is Associated with Situs Inversus Totalis, Human mutation 37(8) (2016) 727-31.

[125] V.H. Castleman, L. Romio, R. Chodhari, R.A. Hirst, S.C. de Castro, K.A. Parker, P. Ybot-Gonzalez, R.D. Emes, S.W. Wilson, C. Wallis, C.A. Johnson, R.J. Herrera, A. Rutman, M. Dixon, A. Shoemark, A. Bush, C. Hogg, R.M. Gardiner, O. Reish, N.D. Greene, C. O'Callaghan, S. Purton, E.M. Chung, H.M. Mitchison, Mutations in radial spoke head protein genes RSPH9 and RSPH4A cause primary ciliary dyskinesia with central-microtubular-pair abnormalities, Am J Hum Genet 84(2) (2009) 197-209.

[126] M.R. Knowles, L.E. Ostrowski, M.W. Leigh, P.R. Sears, S.D. Davis, W.E. Wolf, M.J. Hazucha, J.L. Carson, K.N. Olivier, S.D. Sagel, M. Rosenfeld, T.W. Ferkol, S.D. Dell, C.E. Milla, S.H. Randell, W. Yin, A. Sannuti, H.M. Metjian, P.G. Noone, P.J. Noone, C.A. Olson, M.V. Patrone, H. Dang, H.S. Lee, T.W. Hurd, H.Y. Gee, E.A. Otto, J. Halbritter, S. Kohl, M. Kircher, J. Krischer, M.J. Bamshad, D.A. Nickerson, F. Hildebrandt, J. Shendure, M.A. Zariwala, Mutations in RSPH1 cause primary ciliary dyskinesia with a unique clinical and ciliary phenotype, American journal of respiratory and critical care medicine 189(6) (2014) 707-17.

[127] N.T. Loges, D. Antony, A. Maver, M.A. Deardorff, E.Y. Gulec, A. Gezdirici, T. NotheMenchen, I.M. Hoben, L. Jelten, D. Frank, C. Werner, J. Tebbe, K. Wu, E. Goldmuntz, G. Cuturilo, B. Krock, A. Ritter, R. Hjeij, Z. Bakey, P. Pennekamp, B. Dworniczak, H. Brunner, B. Peterlin, C. Tanidir, H. Olbrich, H. Omran, M. Schmidts, Recessive DNAH9 Loss-of-Function Mutations Cause Laterality Defects and Subtle Respiratory CiliaryBeating Defects, Am J Hum Genet 103(6) (2018) 995-1008.

[128] M.R. Fassad, A. Shoemark, M. Legendre, R.A. Hirst, F. Koll, P. le Borgne, B. Louis, F. Daudvohra, M.P. Patel, L. Thomas, M. Dixon, T. Burgoyne, J. Hayes, A.G. Nicholson, T. Cullup, L. Jenkins, S.B. Carr, P. Aurora, M. Lemullois, A. Aubusson-Fleury, J.F. Papon, C. O'Callaghan, S. Amselem, C. Hogg, E. Escudier, A.M. Tassin, H.M. Mitchison, Mutations in Outer Dynein Arm Heavy Chain DNAH9 Cause Motile Cilia Defects and Situs Inversus, Am J Hum Genet 103(6) (2018) 984-994.

[129] A. Horani, S.L. Brody, T.W. Ferkol, D. Shoseyov, M.G. Wasserman, A. Ta-shma, K.S. Wilson, P.V. Bayly, I. Amirav, M. Cohen-Cymberknoh, S.K. Dutcher, O. Elpeleg, E. Kerem, CCDC65 mutation causes primary ciliary dyskinesia with normal ultrastructure and hyperkinetic cilia, PLoS One 8(8) (2013) e72299.

[130] H. Olbrich, C. Cremers, N.T. Loges, C. Werner, K.G. Nielsen, J.K. Marthin, M. Philipsen, J. Wallmeier, P. Pennekamp, T. Menchen, C. Edelbusch, G.W. Dougherty, O. Schwartz, H. Thiele, J. Altmuller, F. Rommelmann, H. Omran, Loss-of-Function GAS8 Mutations Cause Primary Ciliary Dyskinesia and Disrupt the Nexin-Dynein Regulatory Complex, Am J Hum Genet 97(4) (2015) 546-54.

[131] M. Wirschell, H. Olbrich, C. Werner, D. Tritschler, R. Bower, W.S. Sale, N.T. Loges, P. Pennekamp, S. Lindberg, U. Stenram, B. Carlen, E. Horak, G. Kohler, P. Nurnberg, G. Nurnberg, M.E. Porter, H. Omran, The nexin-dynein regulatory complex subunit DRC1 is essential for motile cilia function in algae and humans, Nature genetics 45(3) (2013) 262-8.

[132] G.J. Vanaken, L. Bassinet, M. Boon, R. Mani, I. Honore, J.F. Papon, H. Cuppens, M. Jaspers, N. Lorent, A. Coste, E. Escudier, S. Amselem, B. Maitre, M. Legendre, S. Christin-Maitre, Infertility in an adult cohort with primary ciliary dyskinesia: phenotypegene association, Eur Respir J 50(5) (2017).

[133] M. Fliegauf, H. Olbrich, J. Horvath, J.H. Wildhaber, M.A. Zariwala, M. Kennedy, M.R. Knowles, $\mathrm{H}$. Omran, Mislocalization of DNAH5 and DNAH9 in respiratory cells from 
patients with primary ciliary dyskinesia, American journal of respiratory and critical care medicine 171(12) (2005) 1343-9.

[134] C. Liu, H. Miyata, Y. Gao, Y. Sha, S. Tang, Z. Xu, M. Whitfield, C. Patrat, H. Wu, E. Dulioust, S. Tian, K. Shimada, J. Cong, T. Noda, H. Li, A. Morohoshi, C. Cazin, Z.E. Kherraf, C. Arnoult, L. Jin, X. He, P.F. Ray, Y. Cao, A. Toure, F. Zhang, M. Ikawa, Biallelic DNAH8 Variants Lead to Multiple Morphological Abnormalities of the Sperm Flagella and Primary Male Infertility, Am J Hum Genet 107(2) (2020) 330-341.

[135] M. Whitfield, L. Thomas, E. Bequignon, A. Schmitt, L. Stouvenel, G. Montantin, S. Tissier, P. Duquesnoy, B. Copin, S. Chantot, F. Dastot, C. Faucon, A.L. Barbotin, A. Loyens, J.P. Siffroi, J.F. Papon, E. Escudier, S. Amselem, V. Mitchell, A. Toure, M. Legendre, Mutations in DNAH17, Encoding a Sperm-Specific Axonemal Outer Dynein Arm Heavy Chain, Cause Isolated Male Infertility Due to Asthenozoospermia, Am J Hum Genet 105(1) (2019) 198-212.

[136] A. Onoufriadis, T. Paff, D. Antony, A. Shoemark, D. Micha, B. Kuyt, M. Schmidts, S. Petridi, J.E. Dankert-Roelse, E.G. Haarman, J.M. Daniels, R.D. Emes, R. Wilson, C. Hogg, P.J. Scambler, E.M. Chung, Uk10K, G. Pals, H.M. Mitchison, Splice-site mutations in the axonemal outer dynein arm docking complex gene CCDC114 cause primary ciliary dyskinesia, Am J Hum Genet 92(1) (2013) 88-98.

[137] S. Cindric, G.W. Dougherty, H. Olbrich, R. Hjeij, N.T. Loges, I. Amirav, M.C. Philipsen, J.K. Marthin, K.G. Nielsen, S. Sutharsan, J. Raidt, C. Werner, P. Pennekamp, B. Dworniczak, H. Omran, SPEF2- and HYDIN-Mutant Cilia Lack the Central Pairassociated Protein SPEF2, Aiding Primary Ciliary Dyskinesia Diagnostics, American journal of respiratory cell and molecular biology 62(3) (2020) 382-396.

[138] A. Sironen, A. Shoemark, M. Patel, M.R. Loebinger, H.M. Mitchison, Sperm defects in primary ciliary dyskinesia and related causes of male infertility, Cellular and molecular life sciences : CMLS 77(11) (2020) 2029-2048.

[139] J. Raidt, C. Werner, T. Menchen, G.W. Dougherty, H. Olbrich, N.T. Loges, R. Schmitz, P. Pennekamp, H. Omran, Ciliary function and motor protein composition of human fallopian tubes, Human reproduction 30(12) (2015) 2871-80.

[140] A. Moore, E. Escudier, G. Roger, A. Tamalet, B. Pelosse, S. Marlin, A. Clement, M. Geremek, B. Delaisi, A.M. Bridoux, A. Coste, M. Witt, B. Duriez, S. Amselem, RPGR is mutated in patients with a complex $X$ linked phenotype combining primary ciliary dyskinesia and retinitis pigmentosa, Journal of medical genetics 43(4) (2006) 326-33.

[141] J.F. Papon, I. Perrault, A. Coste, B. Louis, X. Gerard, S. Hanein, L. Fares-Taie, S. Gerber, S. Defoort-Dhellemmes, A.M. Vojtek, J. Kaplan, J.M. Rozet, E. Escudier, Abnormal respiratory cilia in non-syndromic Leber congenital amaurosis with CEP290 mutations, Journal of medical genetics 47(12) (2010) 829-34.

[142] S. Moalem, S. Keating, P. Shannon, M. Thompson, K. Millar, K. Nykamp, A. Forster, A. Noor, D. Chitayat, Broadening the ciliopathy spectrum: motile cilia dyskinesia, and nephronophthisis associated with a previously unreported homozygous mutation in the INVS/NPHP2 gene, American journal of medical genetics. Part A 161A(7) (2013) 1792-6.

[143] B. Budny, W. Chen, H. Omran, M. Fliegauf, A. Tzschach, M. Wisniewska, L.R. Jensen, M. Raynaud, S.A. Shoichet, M. Badura, S. Lenzner, A. Latos-Bielenska, H.H. Ropers, A novel $X$-linked recessive mental retardation syndrome comprising macrocephaly and ciliary dysfunction is allelic to oral-facial-digital type I syndrome, Human genetics 120(2) (2006) 171-8.

[144] Z. Bukowy-Bieryllo, A. Rabiasz, M. Dabrowski, A. Pogorzelski, A. Wojda, H. Dmenska, K. Grzela, J. Sroczynski, M. Witt, E. Zietkiewicz, Truncating mutations in exons 20 and 21 of OFD1 can cause primary ciliary dyskinesia without associated syndromic symptoms, Journal of medical genetics 56(11) (2019) 769-777.

[145] W.B. Hannah, S. DeBrosse, B. Kinghorn, S. Strausbaugh, M.L. Aitken, M. Rosenfeld, W.E. Wolf, M.R. Knowles, M.A. Zariwala, The expanding phenotype of OFD1-related disorders: Hemizygous loss-of-function variants in three patients with primary ciliary dyskinesia, Molecular genetics \& genomic medicine 7(9) (2019) e911. 
[146] A. Shoemark, M. Dixon, P.L. Beales, C.L. Hogg, Bardet Biedl syndrome: motile ciliary phenotype, Chest 147(3) (2015) 764-770.

[147] A. Patir, A.M. Fraser, M.W. Barnett, L. McTeir, J. Rainger, M.G. Davey, T.C. Freeman, The transcriptional signature associated with human motile cilia, Scientific reports 10(1) (2020) 10814.

[148] M.Z. Nikolic, D. Sun, E.L. Rawlins, Human lung development: recent progress and new challenges, Development 145(16) (2018).

[149] L.E. Zaragosi, M. Deprez, P. Barbry, Using single-cell RNA sequencing to unravel cell lineage relationships in the respiratory tract, Biochem Soc Trans 48(1) (2020) 327-336.

[150] B.A. Afzelius, Genetical and ultrastructural aspects of the immotile-cilia syndrome, Am J Hum Genet 33(6) (1981) 852-64.

[151] G. Pennarun, E. Escudier, C. Chapelin, A.M. Bridoux, V. Cacheux, G. Roger, A. Clement, M. Goossens, S. Amselem, B. Duriez, Loss-of-function mutations in a human gene related to Chlamydomonas reinhardtii dynein IC78 result in primary ciliary dyskinesia, Am J Hum Genet 65(6) (1999) 1508-19.

[152] J. Lin, W. Yin, M.C. Smith, K. Song, M.W. Leigh, M.A. Zariwala, M.R. Knowles, L.E. Ostrowski, D. Nicastro, Cryo-electron tomography reveals ciliary defects underlying human RSPH1 primary ciliary dyskinesia, Nat Commun 5 (2014) 5727.

[153] D.J. Moore, A. Onoufriadis, A. Shoemark, M.A. Simpson, P.I. zur Lage, S.C. de Castro, L. Bartoloni, G. Gallone, S. Petridi, W.J. Woollard, D. Antony, M. Schmidts, T.

Didonna, P. Makrythanasis, J. Bevillard, N.P. Mongan, J. Djakow, G. Pals, J.S. Lucas, J.K. Marthin, K.G. Nielsen, F. Santoni, M. Guipponi, C. Hogg, S.E. Antonarakis, R.D. Emes, E.M. Chung, N.D. Greene, J.L. Blouin, A.P. Jarman, H.M. Mitchison, Mutations in ZMYND10, a gene essential for proper axonemal assembly of inner and outer dynein arms in humans and flies, cause primary ciliary dyskinesia, Am J Hum Genet 93(2) (2013) 346-56.

[154] R. Hjeij, A. Lindstrand, R. Francis, M.A. Zariwala, X. Liu, Y. Li, R. Damerla, G.W. Dougherty, M. Abouhamed, H. Olbrich, N.T. Loges, P. Pennekamp, E.E. Davis, C.M. Carvalho, D. Pehlivan, C. Werner, J. Raidt, G. Kohler, K. Haffner, M. Reyes-Mugica, J.R. Lupski, M.W. Leigh, M. Rosenfeld, L.C. Morgan, M.R. Knowles, C.W. Lo, N. Katsanis, $\mathrm{H}$. Omran, ARMC4 mutations cause primary ciliary dyskinesia with randomization of left/right body asymmetry, Am J Hum Genet 93(2) (2013) 357-67.

[155] M.M. Alsaadi, A.M. Erzurumluoglu, S. Rodriguez, P.A. Guthrie, T.R. Gaunt, H.Z. Omar, M. Mubarak, K.K. Alharbi, A.C. Al-Rikabi, I.N. Day, Nonsense mutation in coiled-coil domain containing 151 gene (CCDC151) causes primary ciliary dyskinesia, Human mutation 35(12) (2014) 1446-8.

[156] R. Hjeij, A. Onoufriadis, C.M. Watson, C.E. Slagle, N.T. Klena, G.W. Dougherty, M. Kurkowiak, N.T. Loges, C.P. Diggle, N.F. Morante, G.C. Gabriel, K.L. Lemke, Y. Li, P. Pennekamp, T. Menchen, F. Konert, J.K. Marthin, D.A. Mans, S.J. Letteboer, C. Werner, T. Burgoyne, C. Westermann, A. Rutman, I.M. Carr, C. O'Callaghan, E. Moya, E.M. Chung, U.K. Consortium, E. Sheridan, K.G. Nielsen, R. Roepman, K. Bartscherer, R.D. Burdine, C.W. Lo, H. Omran, H.M. Mitchison, CCDC151 mutations cause primary ciliary dyskinesia by disruption of the outer dynein arm docking complex formation, Am J Hum Genet 95(3) (2014) 257-74.

[157] M.R. Knowles, M.W. Leigh, L.E. Ostrowski, L. Huang, J.L. Carson, M.J. Hazucha, W. Yin, J.S. Berg, S.D. Davis, S.D. Dell, T.W. Ferkol, M. Rosenfeld, S.D. Sagel, C.E. Milla, K.N. Olivier, E.H. Turner, A.P. Lewis, M.J. Bamshad, D.A. Nickerson, J. Shendure, M.A. Zariwala, C. Genetic Disorders of Mucociliary Clearance, Exome sequencing identifies mutations in CCDC114 as a cause of primary ciliary dyskinesia, Am J Hum Genet 92(1) (2013) 99-106.

[158] H. Olbrich, K. Haffner, A. Kispert, A. Volkel, A. Volz, G. Sasmaz, R. Reinhardt, S. Hennig, H. Lehrach, N. Konietzko, M. Zariwala, P.G. Noone, M. Knowles, H.M. Mitchison, M. Meeks, E.M. Chung, F. Hildebrandt, R. Sudbrak, H. Omran, Mutations in DNAH5 cause primary ciliary dyskinesia and randomization of left-right asymmetry, Nature genetics 30(2) (2002) 143-4. 
[159] L. Bartoloni, J.L. Blouin, Y. Pan, C. Gehrig, A.K. Maiti, N. Scamuffa, C. Rossier, M. Jorissen, M. Armengot, M. Meeks, H.M. Mitchison, E.M. Chung, C.D. DelozierBlanchet, W.J. Craigen, S.E. Antonarakis, Mutations in the DNAH11 (axonemal heavy chain dynein type 11) gene cause one form of situs inversus totalis and most likely primary ciliary dyskinesia, Proceedings of the National Academy of Sciences of the United States of America 99(16) (2002) 10282-6.

[160] N.T. Loges, H. Olbrich, L. Fenske, H. Mussaffi, J. Horvath, M. Fliegauf, H. Kuhl, G. Baktai, E. Peterffy, R. Chodhari, E.M. Chung, A. Rutman, C. O'Callaghan, H. Blau, L. Tiszlavicz, K. Voelkel, M. Witt, E. Zietkiewicz, J. Neesen, R. Reinhardt, H.M. Mitchison, $\mathrm{H}$. Omran, DNAI2 mutations cause primary ciliary dyskinesia with defects in the outer dynein arm, Am J Hum Genet 83(5) (2008) 547-58.

[161] J. Horvath, M. Fliegauf, H. Olbrich, A. Kispert, S.M. King, H. Mitchison, M.A. Zariwala, M.R. Knowles, R. Sudbrak, G. Fekete, J. Neesen, R. Reinhardt, H. Omran, Identification and analysis of axonemal dynein light chain 1 in primary ciliary dyskinesia patients, American journal of respiratory cell and molecular biology 33(1) (2005) 41-7.

[162] J. Wallmeier, H. Shiratori, G.W. Dougherty, C. Edelbusch, R. Hjeij, N.T. Loges, T. Menchen, H. Olbrich, P. Pennekamp, J. Raidt, C. Werner, K. Minegishi, K. Shinohara, Y. Asai, K. Takaoka, C. Lee, M. Griese, Y. Memari, R. Durbin, A. Kolb-Kokocinski, S. Sauer, J.B. Wallingford, H. Hamada, H. Omran, TTC25 Deficiency Results in Defects of the Outer Dynein Arm Docking Machinery and Primary Ciliary Dyskinesia with LeftRight Body Asymmetry Randomization, Am J Hum Genet 99(2) (2016) 460-9.

[163] J.R. Panizzi, A. Becker-Heck, V.H. Castleman, D.A. Al-Mutairi, Y. Liu, N.T. Loges, N. Pathak, C. Austin-Tse, E. Sheridan, M. Schmidts, H. Olbrich, C. Werner, K. Haffner, N. Hellman, R. Chodhari, A. Gupta, A. Kramer-Zucker, F. Olale, R.D. Burdine, A.F. Schier, C. O'Callaghan, E.M. Chung, R. Reinhardt, H.M. Mitchison, S.M. King, H. Omran, I.A. Drummond, CCDC103 mutations cause primary ciliary dyskinesia by disrupting assembly of ciliary dynein arms, Nature genetics 44(6) (2012) 714-9.

[164] I.M. Hoben, R. Hjeij, H. Olbrich, G.W. Dougherty, T. Nothe-Menchen, I. Aprea, D. Frank, P. Pennekamp, B. Dworniczak, J. Wallmeier, J. Raidt, K.G. Nielsen, M.C. Philipsen, F. Santamaria, L. Venditto, I. Amirav, H. Mussaffi, F. Prenzel, K. Wu, Z. Bakey, M. Schmidts, N.T. Loges, H. Omran, Mutations in C11orf70 Cause Primary Ciliary Dyskinesia with Randomization of Left/Right Body Asymmetry Due to Defects of Outer and Inner Dynein Arms, Am J Hum Genet 102(5) (2018) 973-984.

[165] P. Duquesnoy, E. Escudier, L. Vincensini, J. Freshour, A.M. Bridoux, A. Coste, A. Deschildre, J. de Blic, M. Legendre, G. Montantin, H. Tenreiro, A.M. Vojtek, C. Loussert, A. Clement, D. Escalier, P. Bastin, D.R. Mitchell, S. Amselem, Loss-offunction mutations in the human ortholog of Chlamydomonas reinhardtii ODA7 disrupt dynein arm assembly and cause primary ciliary dyskinesia, Am J Hum Genet 85(6) (2009) 890-6.

[166] N.T. Loges, H. Olbrich, A. Becker-Heck, K. Haffner, A. Heer, C. Reinhard, M. Schmidts, A. Kispert, M.A. Zariwala, M.W. Leigh, M.R. Knowles, H. Zentgraf, H. Seithe, G. Nurnberg, P. Nurnberg, R. Reinhardt, H. Omran, Deletions and point mutations of LRRC50 cause primary ciliary dyskinesia due to dynein arm defects, Am J Hum Genet 85(6) (2009) 883-9.

[167] A. Tarkar, N.T. Loges, C.E. Slagle, R. Francis, G.W. Dougherty, J.V. Tamayo, B. Shook, M. Cantino, D. Schwartz, C. Jahnke, H. Olbrich, C. Werner, J. Raidt, P. Pennekamp, M. Abouhamed, R. Hjeij, G. Kohler, M. Griese, Y. Li, K. Lemke, N. Klena, X. Liu, G. Gabriel, K. Tobita, M. Jaspers, L.C. Morgan, A.J. Shapiro, S.J. Letteboer, D.A. Mans, J.L. Carson, M.W. Leigh, W.E. Wolf, S. Chen, J.S. Lucas, A. Onoufriadis, V. Plagnol, M. Schmidts, K. Boldt, Uk10K, R. Roepman, M.A. Zariwala, C.W. Lo, H.M. Mitchison, M.R. Knowles, R.D. Burdine, J.J. Loturco, H. Omran, DYX1C1 is required for axonemal dynein assembly and ciliary motility, Nature genetics 45(9) (2013) 9951003. 
[168] A. Horani, T.E. Druley, M.A. Zariwala, A.C. Patel, B.T. Levinson, L.G. Van Arendonk, K.C. Thornton, J.C. Giacalone, A.J. Albee, K.S. Wilson, E.H. Turner, D.A. Nickerson, J. Shendure, P.V. Bayly, M.W. Leigh, M.R. Knowles, S.L. Brody, S.K. Dutcher, T.W. Ferkol, Whole-exome capture and sequencing identifies HEATR2 mutation as a cause of primary ciliary dyskinesia, Am J Hum Genet 91(4) (2012) 685-93.

[169] T. Paff, N.T. Loges, I. Aprea, K. Wu, Z. Bakey, E.G. Haarman, J.M.A. Daniels, E.A. Sistermans, N. Bogunovic, G.W. Dougherty, I.M. Hoben, J. Grosse-Onnebrink, A. Matter, H. Olbrich, C. Werner, G. Pals, M. Schmidts, H. Omran, D. Micha, Mutations in PIH1D3 Cause X-Linked Primary Ciliary Dyskinesia with Outer and Inner Dynein Arm Defects, Am J Hum Genet 100(1) (2017) 160-168.

[170] E. Kott, P. Duquesnoy, B. Copin, M. Legendre, F. Dastot-Le Moal, G. Montantin, L. Jeanson, A. Tamalet, J.F. Papon, J.P. Siffroi, N. Rives, V. Mitchell, J. de Blic, A. Coste, A. Clement, D. Escalier, A. Toure, E. Escudier, S. Amselem, Loss-of-function mutations in LRRC6, a gene essential for proper axonemal assembly of inner and outer dynein arms, cause primary ciliary dyskinesia, Am J Hum Genet 91(5) (2012) 958-64.

[171] M.R. Knowles, L.E. Ostrowski, N.T. Loges, T. Hurd, M.W. Leigh, L. Huang, W.E. Wolf, J.L. Carson, M.J. Hazucha, W. Yin, S.D. Davis, S.D. Dell, T.W. Ferkol, S.D. Sagel, K.N. Olivier, C. Jahnke, H. Olbrich, C. Werner, J. Raidt, J. Wallmeier, P. Pennekamp, G.W. Dougherty, R. Hjeij, H.Y. Gee, E.A. Otto, J. Halbritter, M. Chaki, K.A. Diaz, D.A. Braun, J.D. Porath, M. Schueler, G. Baktai, M. Griese, E.H. Turner, A.P. Lewis, M.J. Bamshad, D.A. Nickerson, F. Hildebrandt, J. Shendure, H. Omran, M.A. Zariwala, Mutations in SPAG1 cause primary ciliary dyskinesia associated with defective outer and inner dynein arms, Am J Hum Genet 93(4) (2013) 711-20.

[172] M.A. Zariwala, H.Y. Gee, M. Kurkowiak, D.A. Al-Mutairi, M.W. Leigh, T.W. Hurd, R. Hjeij, S.D. Dell, M. Chaki, G.W. Dougherty, M. Adan, P.C. Spear, J. Esteve-Rudd, N.T. Loges, M. Rosenfeld, K.A. Diaz, H. Olbrich, W.E. Wolf, E. Sheridan, T.F. Batten, J. Halbritter, J.D. Porath, S. Kohl, S. Lovric, D.Y. Hwang, J.E. Pittman, K.A. Burns, T.W. Ferkol, S.D. Sagel, K.N. Olivier, L.C. Morgan, C. Werner, J. Raidt, P. Pennekamp, Z. Sun, W. Zhou, R. Airik, S. Natarajan, S.J. Allen, I. Amirav, D. Wieczorek, K. Landwehr, K. Nielsen, N. Schwerk, J. Sertic, G. Kohler, J. Washburn, S. Levy, S. Fan, C. Koerner-Rettberg, S. Amselem, D.S. Williams, B.J. Mitchell, I.A. Drummond, E.A. Otto, H. Omran, M.R. Knowles, F. Hildebrandt, ZMYND10 is mutated in primary ciliary dyskinesia and interacts with LRRC6, Am J Hum Genet 93(2) (2013) 336-45.

[173] X.M. Bustamante-Marin, A. Shapiro, P.R. Sears, W.L. Charng, D.F. Conrad, M.W. Leigh, M.R. Knowles, L.E. Ostrowski, M.A. Zariwala, Identification of genetic variants in CFAP221 as a cause of primary ciliary dyskinesia, Journal of human genetics 65(2) (2020) 175-180.

[174] E. El Khouri, L. Thomas, L. Jeanson, E. Bequignon, B. Vallette, P. Duquesnoy, G. Montantin, B. Copin, F. Dastot-Le Moal, S. Blanchon, J.F. Papon, P. Lores, L. Yuan, N. Collot, S. Tissier, C. Faucon, G. Gacon, C. Patrat, J.P. Wolf, E. Dulioust, B. Crestani, E. Escudier, A. Coste, M. Legendre, A. Toure, S. Amselem, Mutations in DNAJB13, Encoding an HSP40 Family Member, Cause Primary Ciliary Dyskinesia and Male Infertility, Am J Hum Genet 99(2) (2016) 489-500.

[175] H. Olbrich, M. Schmidts, C. Werner, A. Onoufriadis, N.T. Loges, J. Raidt, N.F. Banki, A. Shoemark, T. Burgoyne, S. Al Turki, M.E. Hurles, U.K. Consortium, G. Kohler, J. Schroeder, G. Nurnberg, P. Nurnberg, E.M. Chung, R. Reinhardt, J.K. Marthin, K.G. Nielsen, H.M. Mitchison, H. Omran, Recessive HYDIN mutations cause primary ciliary dyskinesia without randomization of left-right body asymmetry, Am J Hum Genet 91(4) (2012) 672-84.

[176] E.H. Cho, H.J. Huh, I. Jeong, N.Y. Lee, W.J. Koh, H.C. Park, C.S. Ki, A nonsense variant in NME5 causes human primary ciliary dyskinesia with radial spoke defects, Clinical genetics 98(1) (2020) 64-68.

[177] E. Kott, M. Legendre, B. Copin, J.F. Papon, F. Dastot-Le Moal, G. Montantin, P. Duquesnoy, W. Piterboth, D. Amram, L. Bassinet, J. Beucher, N. Beydon, E. 
Deneuville, V. Houdouin, H. Journel, J. Just, N. Nathan, A. Tamalet, N. Collot, L. Jeanson, M. Le Gouez, B. Vallette, A.M. Vojtek, R. Epaud, A. Coste, A. Clement, B. Housset, B. Louis, E. Escudier, S. Amselem, Loss-of-function mutations in RSPH1 cause primary ciliary dyskinesia with central-complex and radial-spoke defects, Am J Hum Genet 93(3) (2013) 561-70.

[178] L. Jeanson, B. Copin, J.F. Papon, F. Dastot-Le Moal, P. Duquesnoy, G. Montantin, J. Cadranel, H. Corvol, A. Coste, J. Desir, A. Souayah, E. Kott, N. Collot, S. Tissier, B. Louis, A. Tamalet, J. de Blic, A. Clement, E. Escudier, S. Amselem, M. Legendre, RSPH3 Mutations Cause Primary Ciliary Dyskinesia with Central-Complex Defects and a Near Absence of Radial Spokes, Am J Hum Genet 97(1) (2015) 153-62. 